\title{
The Impact of Board Members' Intellectual Capital on The Performance of Their Roles in State-Owned Enterprises: The Moderating Role of the Board's Incentives
}

Akbar Shariatnia ${ }^{1}$ Ph.D. Student of General Policy, Institute of Management and Planning Studies (IMPS), Tehran, Iran.

Habibollah Taherpoor Kalantari ${ }^{2}$ Assistant Professor of Management, Institute for Management and Planning Studies Tehran, Iran (Corresponding Author).

Ali Jahangiri ${ }^{3}$ Assistant Professor of Management, Institute for Management and Planning Studies, Tehran, Iran.

Mehdi Rasouli Ghahroudi ${ }^{4}$ Assistant Professor of International Business Management, Institute for Management and Planning Studies, Tehran, Iran.

\begin{abstract}
One of the most challenging issues in corporate governance is the reduction of managers' agency costs in state-owned companies. The purpose of this study is to find out if the three board's incentives (financial services compensation, the board's dependency on the CEO and the board's dependency on the government) play a moderating role in the relation between the board's intellectual capital and performance of the board's roles (strategic, control, providing resources and services) in state-owned enterprises. To collect data, 127 state-owned companies were selected and questionnaires, together with structural equation modeling (SEM), were applied. Findings show that the board's intellectual capital has a significant and positive impact on the performance of the board's roles. Furthermore, financial service compensation has not moderated the impact of the board members' intellectual capital on performance of their roles. On the other hand, the findings of this study show that the level of the board's dependency on the CEO has moderated the impact of the board's intellectual capital on strategic role performance in a positive and significant way. Also, results confirm that the level of the board's dependency on government has negatively moderated the impact of their intellectual capital on the control role performance.
\end{abstract}

Keywords: Intellectual Capital, Board Incentives, Corporate Governance, Board Performance Appraisal, State-owned Enterprises.

1. a.shariat@imps.ac.ir

2.h.taherpour@imps.ac.ir

3. a.jahan@imps.ac.ir

4.m.rasouli@imps.ac.ir 
عنوان مقاله: اثر سرمايه فكرى هيئتمديره بر عملكرد

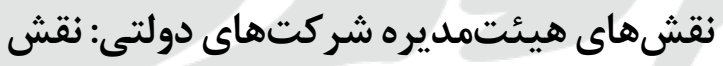

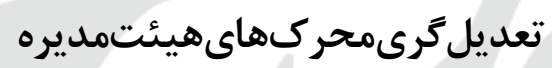

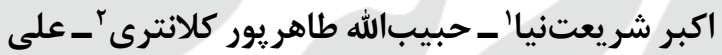

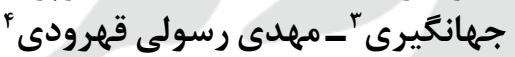

مقاله بروهشى

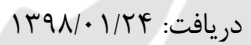

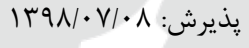

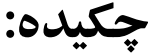

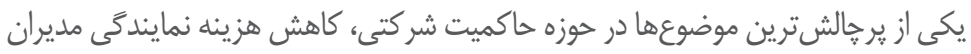

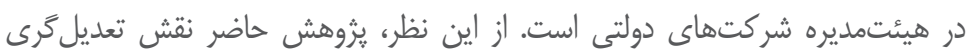

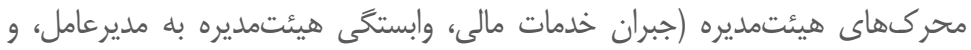

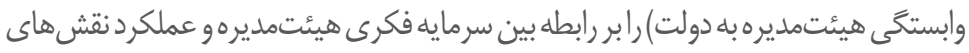

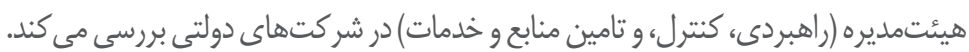

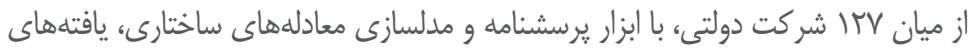

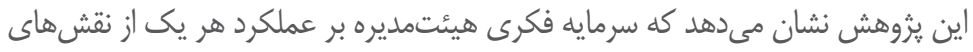

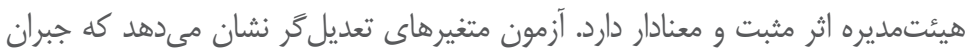

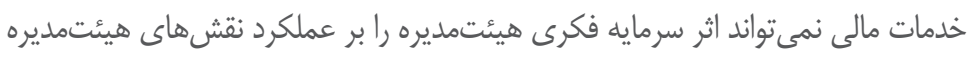

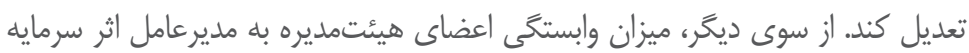

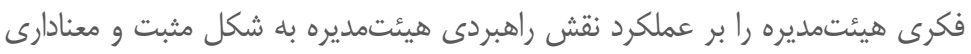

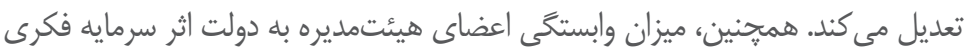

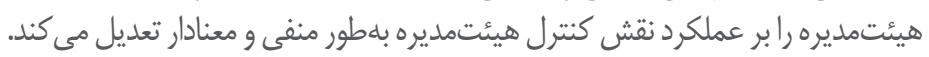

كليدوازهها: سرمايه فكرى، محرك كهاى هيئتمديره، حاكميت

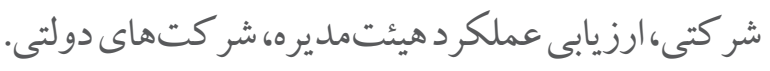

1. دانشجوى دكترى خطمشى كذارى عمومى، موسسه عالى آموزش و يُزوهش مديريت و برنامهريزى، تهران، a.shariat@imps.ac.ir

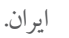
r. استاديار گروه مديريت دولتى، موسسه عالى آموزش و يُزوهش مديريت و برنامهريزى، تهران، ايران h.taherpour@imps.ac.ir

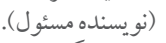

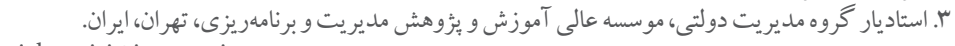
a.jahangiri@imps.ac.ir

F. استاديار كروه مديريت بازر كانى، موسسه عالى آموزش و يُزوهش مديريت و برنامهريزى، تهران، ايران. m.rasouli@imps.ac.ir 


\section{مقلهمه}

در بسيارى از كشورهاى جهان، شركتهاى دولتى كماكان بخش مهمى از توليد ناخالص ملّى،

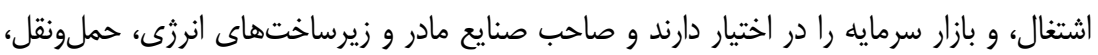

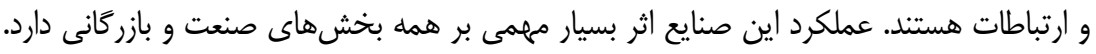

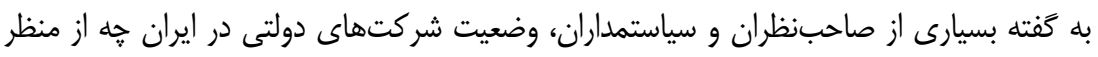

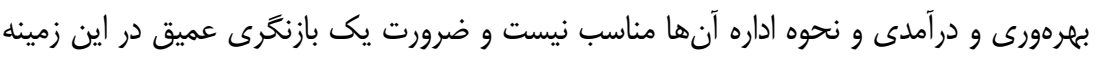

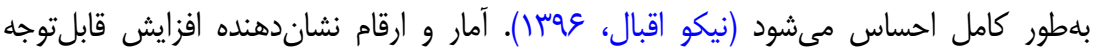

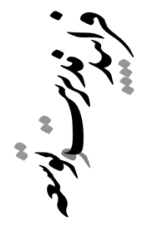

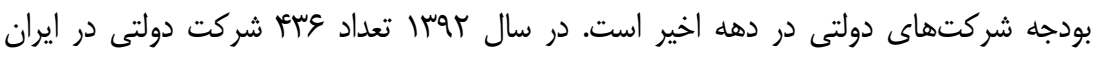

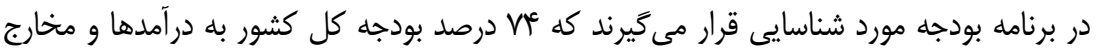

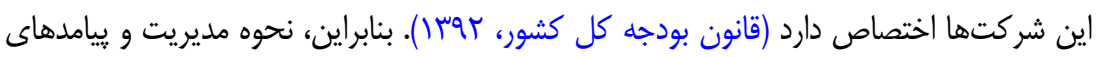
حاصل از فعاليت اين شركتها بر متغيرهاى كلان اقتصادى مانند رشد اقتصادى، ميزان بيكارى،

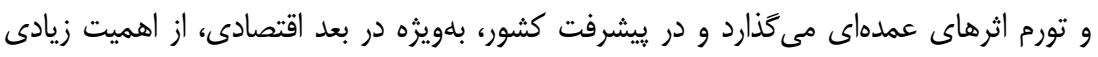

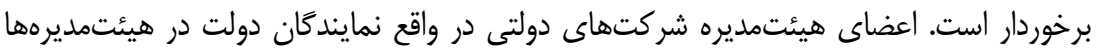

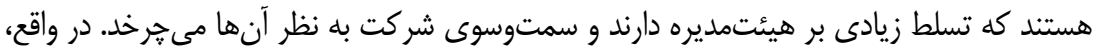

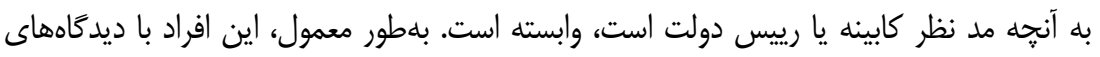

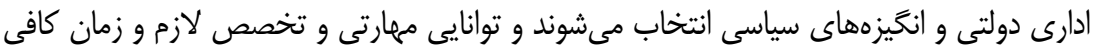

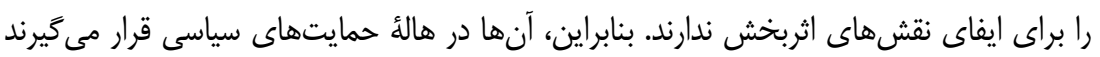
(Mar \& Young, 2001)

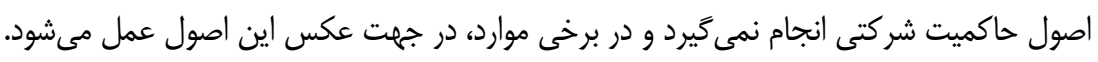

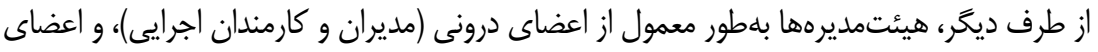

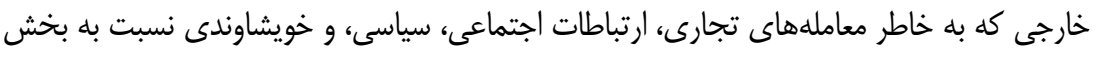

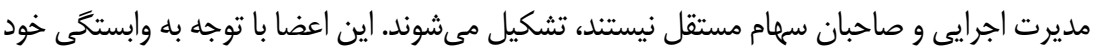

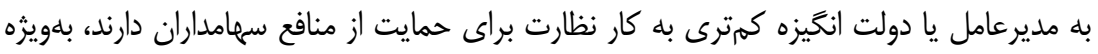
زمانى كه منافع آنها (سهامداران) در تضاد با منافع مديران است (Hillman \& Dalziel, 2003).

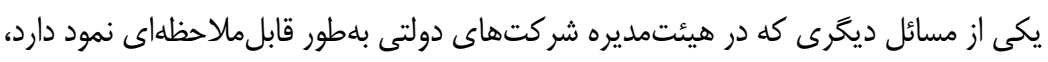


نبود انخيزه كافى اعضاى هيئتمديره براى نظارت بر كار بخش مديريت اجرايى و عملكرد شركت

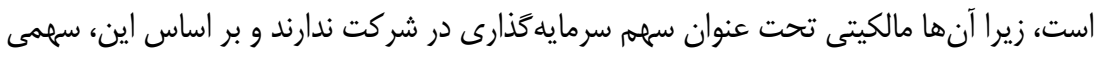

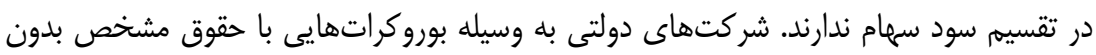

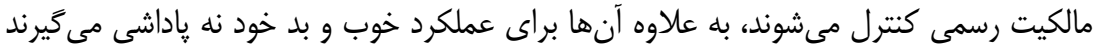

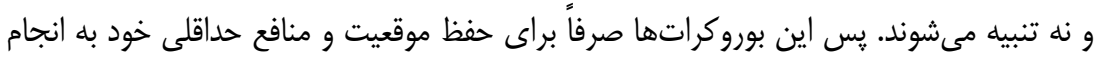
وظايف مىيردازند (Andrews \& Dowling, 1998). در مورد اهميت عملكرد هيئتمديره شركتها اين اعتقاد وجود دارد كه ريشه اصلى مشكارنات الهات

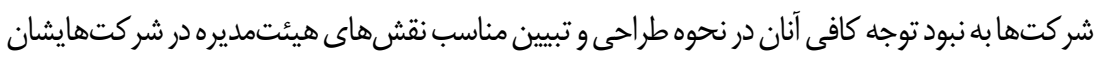
بازمى گردد (Zahra \& Pearce, 1989; Johnson et al., 1996; Stiles \& Taylor, 2001).

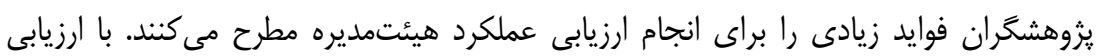

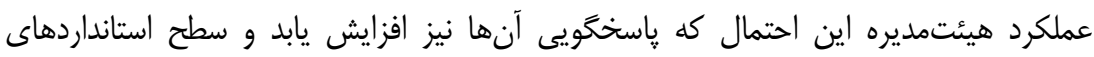

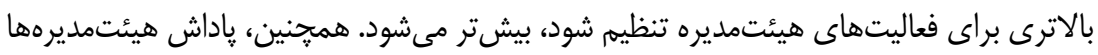

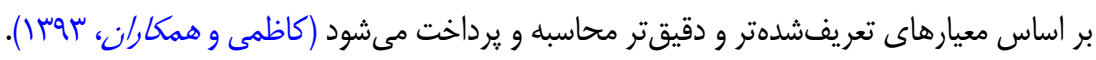

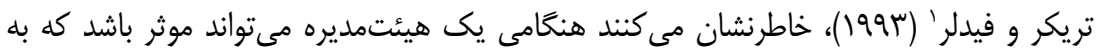

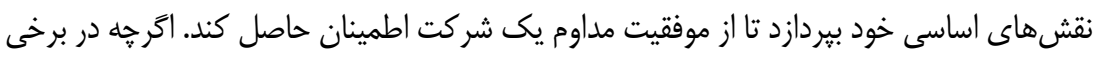

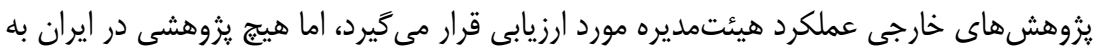

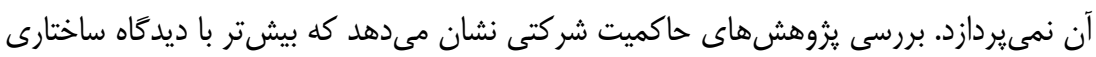

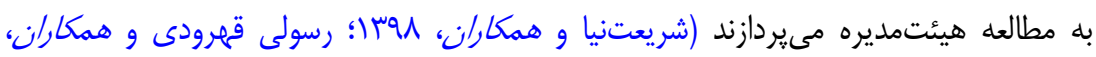

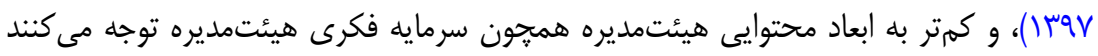

$$
\text { (عنايتيور شياده و همكاران، وجمبر (1). }
$$

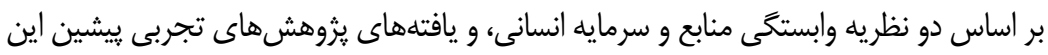

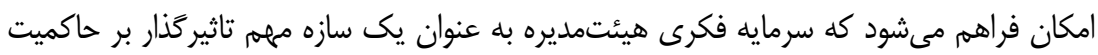

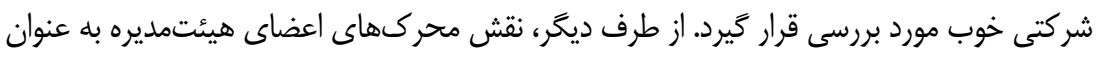

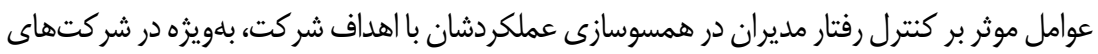

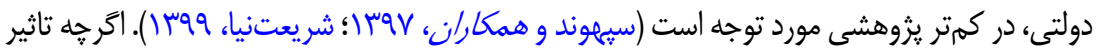

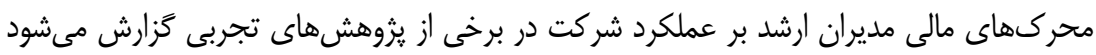

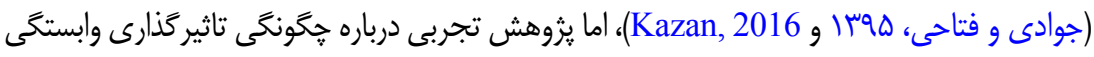

1. Tecker \& Fidler 
اعضاى هيئتمديره به مدير عامل و دولت صورت نكرفته است. دستاورد اين بثروهش به ادبيات موجود

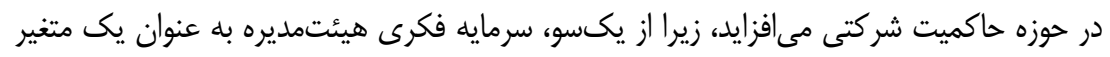

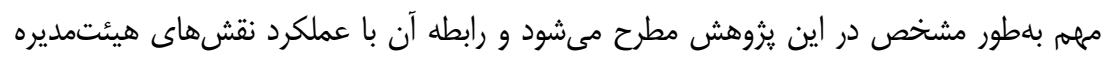

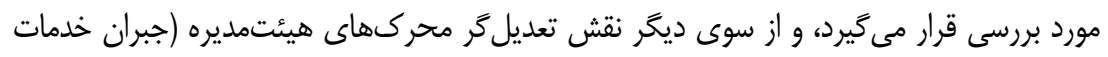

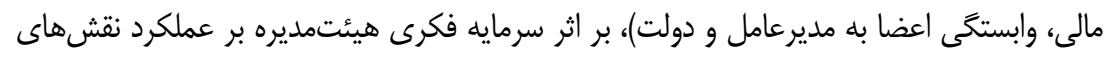

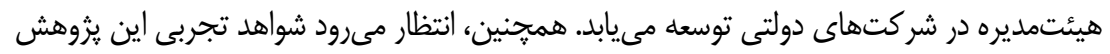

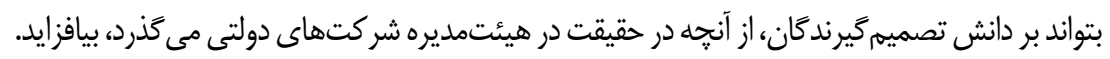

\section{مبانى نظرى ثئوهش}

\section{سرمايه فكرى هيئتمديره}

سرمايه فكرى عبارت است از اتمام قابليتها، دانش، فرهنگ، فرايندها، دارايىهاى فكرى،

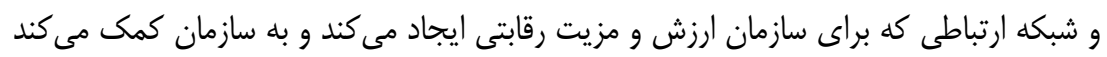

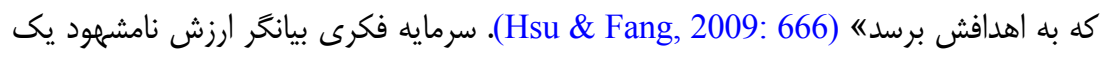

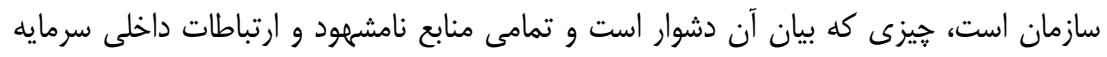

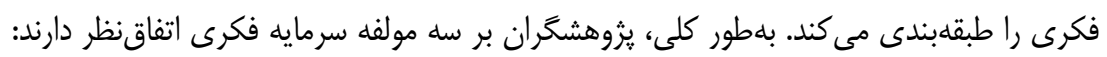

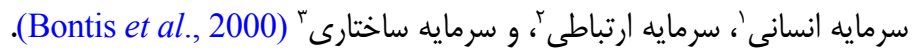

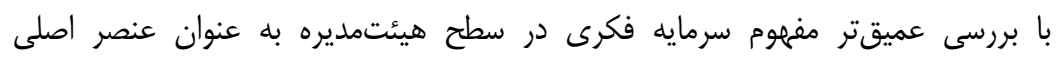

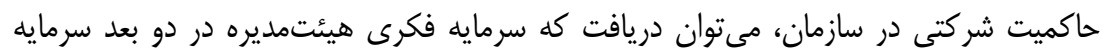

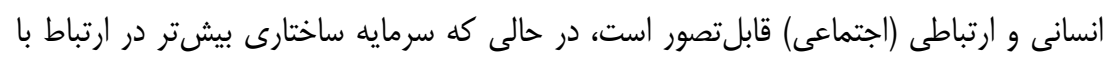

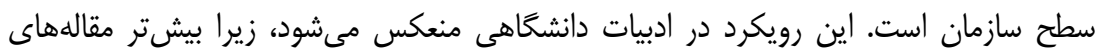

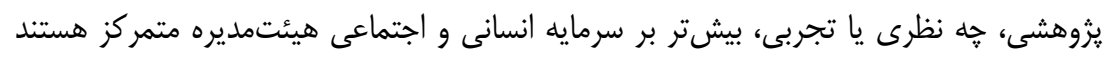
(Mostivenko, 2017; Berezinets et al., 2016)

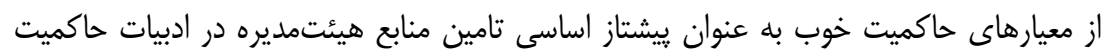

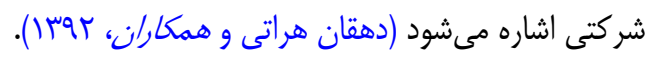

1. Human Capital

2. Relational Capital

3. Structural Capital 


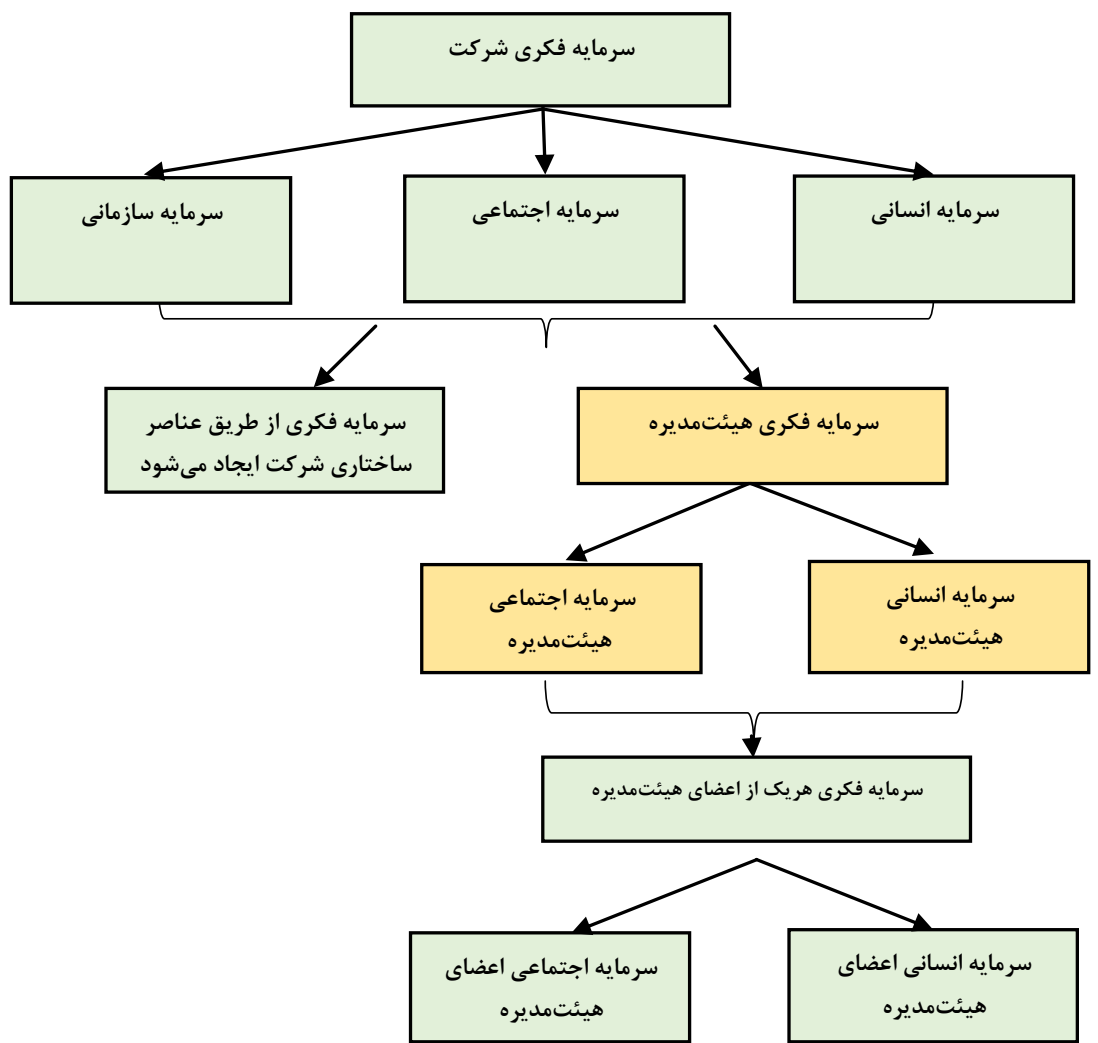

شكل ا: جارجوب عناصر سرمايه فكرى هيئتمديره (Berezinets et al., 2016: 637)

\section{الكوى نظرى نقشهاى هيئتمديره}

با همه مسائلى كه جدايى مالكيت از بخش مديريت شركت در اداره شركت ايجاد مى كند، تمامى يزوهشگران در يك جيز انكارنايذير توافق دارند كه بنحاه اقتصادى بايد بتواند بهطور

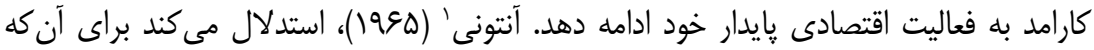

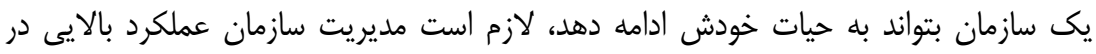
انجام دو وظيفه برنامهريزى راهبردى و كنترل (مديريتى و عملياتى) ايفا كند. اين تقسيهبندى وظايف مديريت در بسيارى از منابع علمى به عنوان يكى از ڤارادايمهاى مديريت نام برده

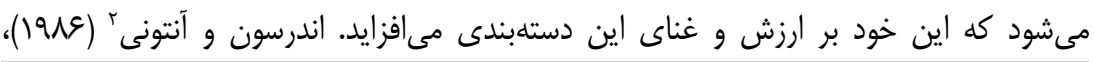

1. Anthony

2. Anderson \& Anthony 
نشان مىدهند كه جَكونه معناى عضويت در هيئتمديره و مسئوليت مديران در مهرومومها از

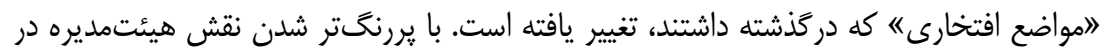
شركتها، ضرورت تعريف و واكاوى نقشهاى هيئتمديره به عنوان مسئول اصلى راهبرى شركت كه عملكرد شركت را تحت تاثير قرار مىدهد، از طرف بسيارى از بزوهشكران مورد تاكيد است نتان (Kiel \& Nicholson, 2003; Sonnenfeld, 2002; Westphal \& Bednar, 2005) نقشهاى اشارهشده براى هيئتمديره در ادبيات را مىتوان در نظريههاى حاكميت شركتى رديابى

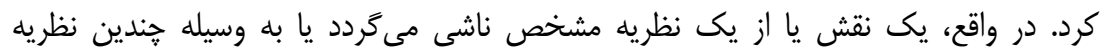

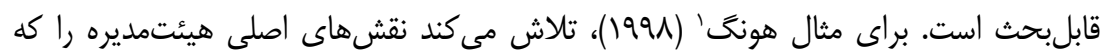

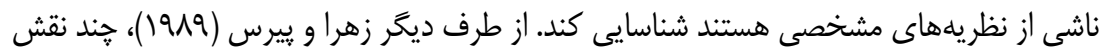

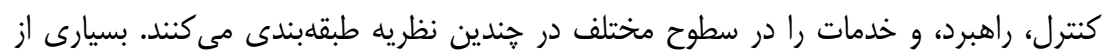

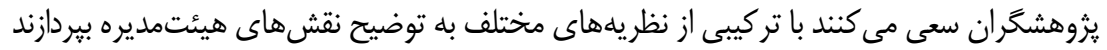

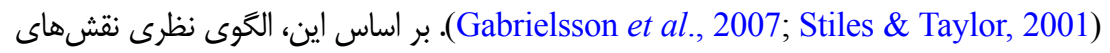
هيئتمديره پِّ از بررسى ادبيات به شكل (T) تبيين مىيابد (Levrau \& Van den Berghe, 2007).

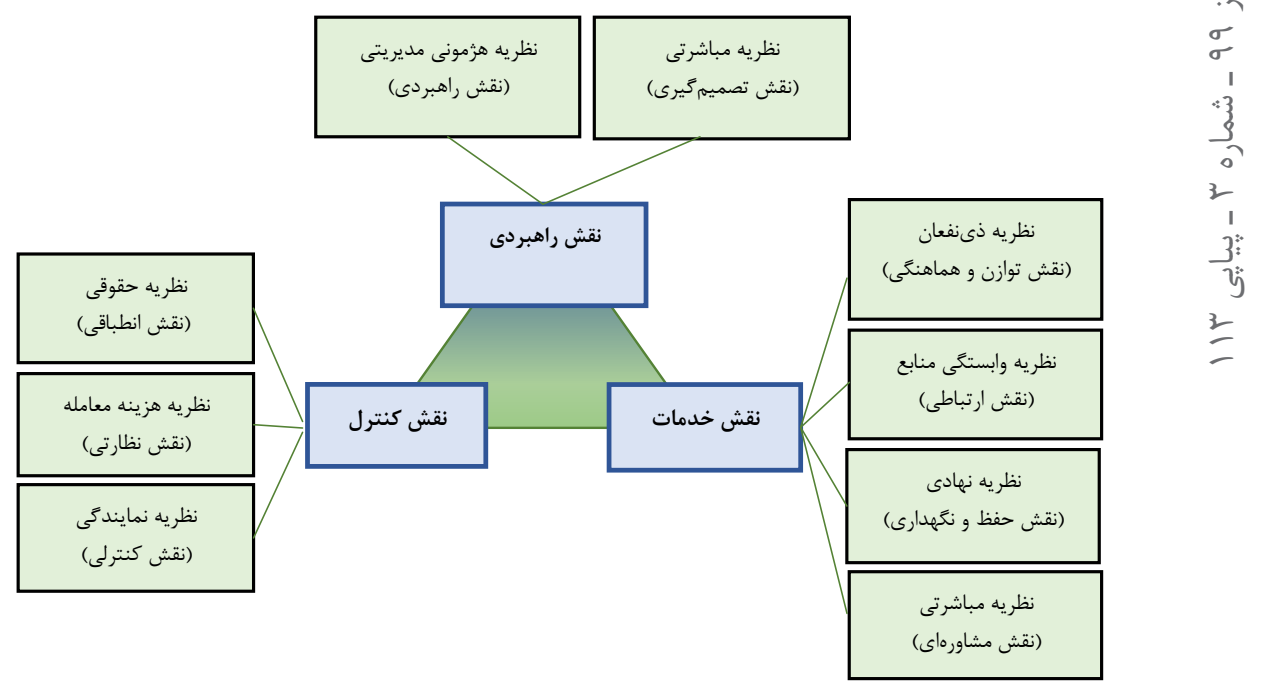

شكل ז: الكوى نظرى نقشهاى هيئتمديره

1. Hung 


\section{محر ككهاى اعضاى هيئتمديره}

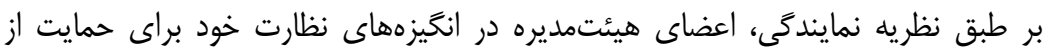
منافع سهامداران متفاوت هستند، در نتيجه، انظيزه يك ييشنياز اصلى براى نظارت موثر است.

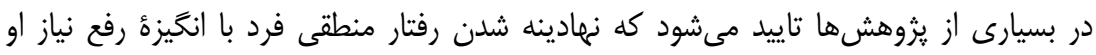

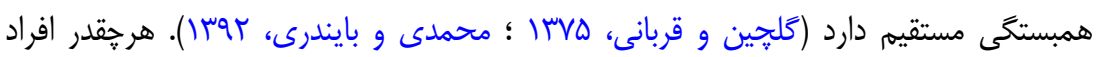
نياز هاى ارضاشده داشته باشند، رفتارشان عقلانىتر و منطقىتر مى شود، يعنى مجموعه فعاليتهاى داى

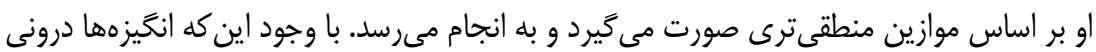

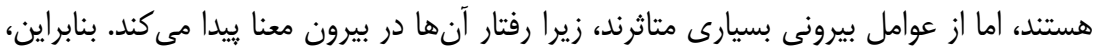

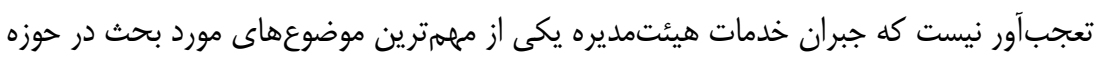
حاكميت شر كتى است (Barontini \& Bozzi, 2011)، كه بلطور قابل توجهى در دو دهه اخير توجه

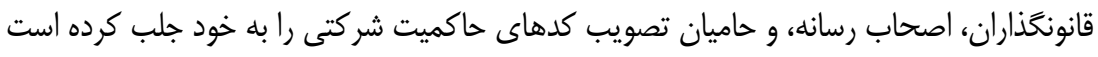

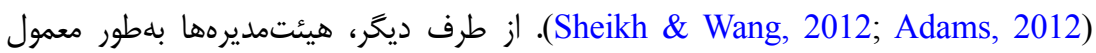

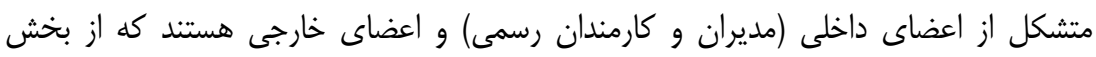

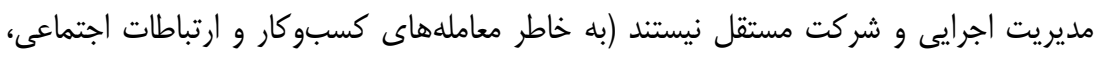
سياسى، و خويشاوندى). يس اين اعضا با توجه به وابستخى خود به مدير عامل شركت / يا سازمان

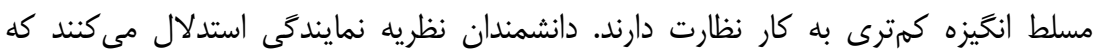

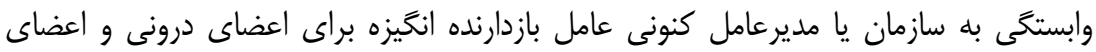

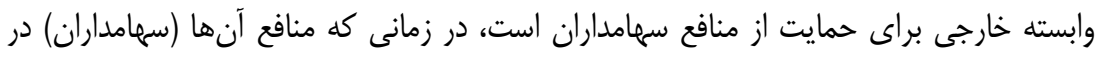

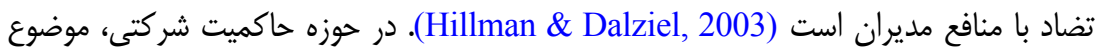

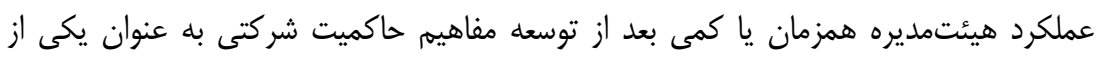

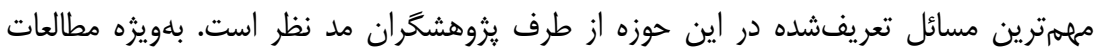

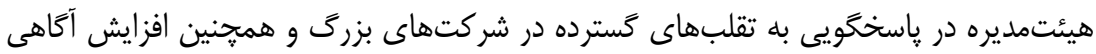

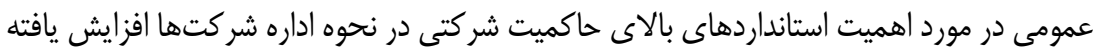

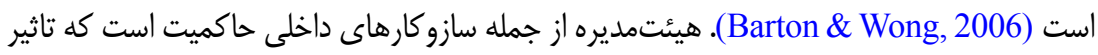

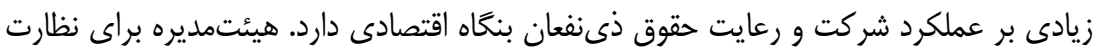

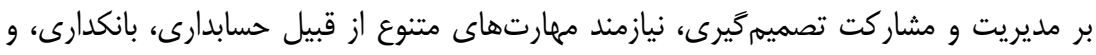
قانون است تا بتواند بر افزايش ارزش شركت موثر باشد. سرمايه فكرى هيئتمديره به به عنوان يكى فيك 
از معيارهاى حاكميت خوب در ادبيات حاكميت شركتى ناديده گرفته شده است (دهقان هراتى و

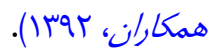

شجاعى و باغبانيان (IMMN)، به بررسى رابطه اجزاى سرمايه فكرى (سرمايه انسانى، سرمايه

ساختارى، و سرمايه ارتباطى) بر عملكرد سازمانى صنعت بانكدارى مىيردازند كه نتايج نشاندهنده ارتباط مثبت معنادارى بين تكتك اجزاى سرمايه فكرى و عملكرد اين شركتهاست. عباسى و و و

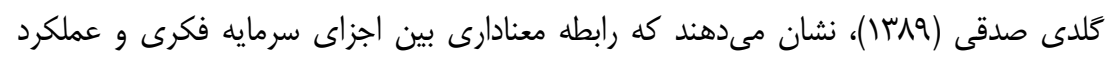

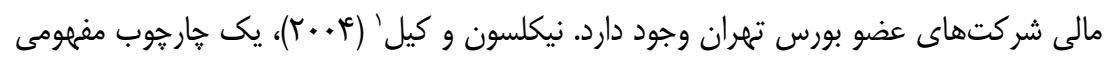
با هدف تبيين هُخونكى اثركذارى سرمايه فكرى هيئتمديره بر خروجى هاى شركت از طريق عملكرد نقشهاى هيئتمديره را توسعه مىدهند. در واقع، با در نظرگرفتن هيئتمديره به عنوان

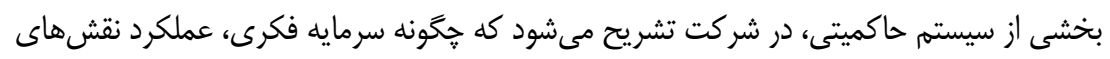

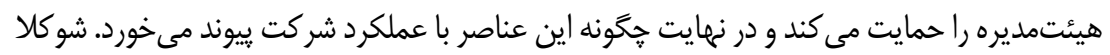

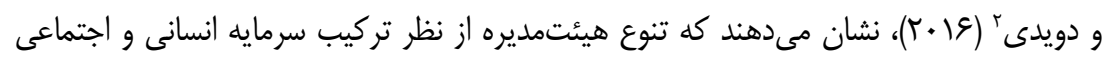

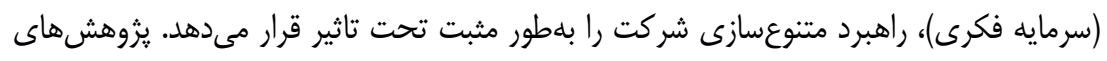

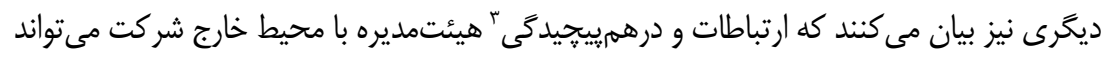
نقش بسيار مهمى در رساندن اطلاعات به شركتها (Burt, 1980)، دستيابى به منابع بحرانى دئى

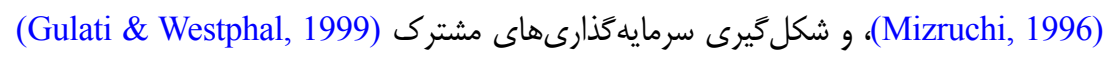

داشته باشد.

در اين راستا، نظريه وابستخى به منابعَ معتقد است اعضاى هيئتمديره يكى از مهمرترين منابع شركتهاست (Emerson, 1962). بلهور خاص، دانش و تجربيات آنها در كسبوكار براى اثربخشى هيئتمديرهها و عملكرد شركت بسيار ضرورى است (Hansell, 2003). براى لئ

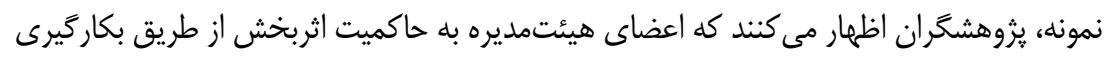
اطلاعات و تخصص لازم با افزايش خلاقيت و انسجام در فرايند تصميمَيرى يارى مىرسانئد

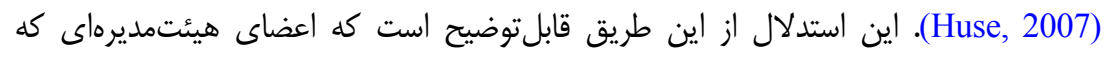
داراى دانش و مهارتهاى مرتبط هستند مىتوانند موثرتر عمل كنند. اين عملكرد مىتواند بلويثه در تجزيهوتحليل ديدگاههاى مختلف (Kiel \& Nicholson, 2003)، و مشاركت در فرايندهاى

1. Nicholson \& Kiel

2. Shukla \& Dwivedi

3. Interlocks

4. Resource Dependency Theory 
راهبردى نمود بيشترى داشته باشد (Offstein \& Gnyawali, 2006).

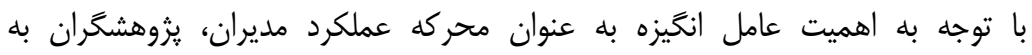
مطالعه رابطه بين محركهاى هيئتمديره و عملكرد هيئتمديره و شركت مىيردازند (Pfeffer, 1972; Hillman \& Dalziel, 2003; Dalton et al., 1998) و همكاران' (V +. (Y)، نشان مى دهد كه رابطه معنادارى بين קاداش اعضاى هيئتمديره و عملكرد شركت وجود ندارد. علاوه بر يرداخت مبتنى بر عملكرد هيئتمديره، مطالعه نشان مىدهد كه سياستهاى مديريتى، اندازه بانك، و مالكيت سهام اعضاى هيئتمديره بر سطح يرداختى تاثير

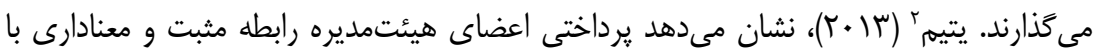
عملكرد مالى و فرصتهاى رشد دارد. از طرف ديگًر، يرداختى اعضاى هيئتمديره رابطه منفى و

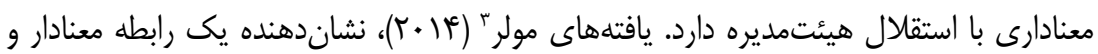
مثبت بين يرداختىهاى هيئتمديره و عملكرد مالى شركت است. با اين حال، يافتههاى ززارششده از يزوهشهاى مختلف نتايج متناقضى را نشان ميىدهد. توضيح اوليه براى اين نتايج متناقض، تفاوتهاى نهادى است كه در كشورها وجود دارد. فيرث و

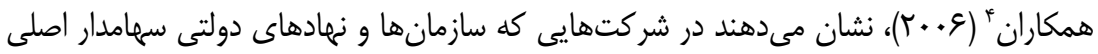
آن هستند، به نظر نمىرسد عملكرد شركت در تعيين طرحهاى پاداش مديران اجرايى مورد توجه ويثه باشد. در مقابل، حقوق مديران در شركتهاى خصوصى با تغيير در ثروت سهامداران مرتبط

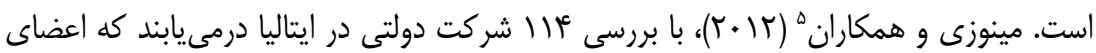
هيئتمديره، كه بلهور سياسى وابسته به دولت (نماينده دولت يا شهردارى محلى) هستند، بر هيئتمديرههاى شركتهاى دولتى ايتاليايى غالب هستند و اعضاى هيئتمديره با وابسته سياسى بـى

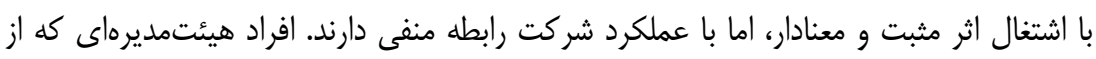
طريق روابط خويشاوندى به عنوان ذىنفعان با شركت ارتباط دارند، با انخَيزه بيشترى براى

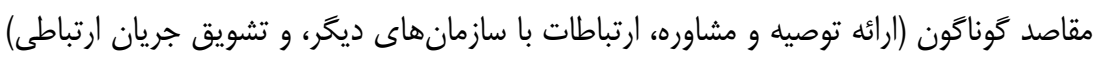
بd كَونهاى عمل مى كنند كه تصوير خارجى شركت بهبود يابد (Dalton et al., 1998). اعضاى

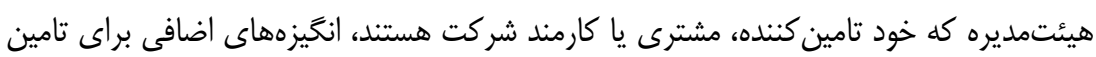

1. Doucouliagos et al.

2. Yatim

3. Müller

4. Firth et al.

5. Menozzi et al. 
منابع شركت دارند، زيرا آنها احتمالاً با بيشينه شدن عملكرد شركت منتفع مىشوند، درست مانند

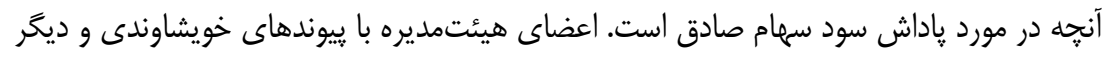

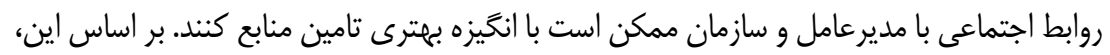
وابستخى هيئتمديره در شركتهاى دولتى مىتواند در دو شكل قابلطرح باشد: ا. وابستخى هاى

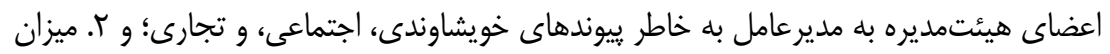

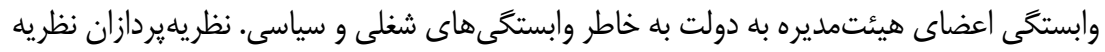

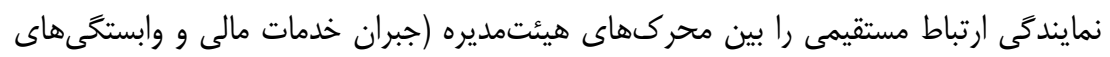

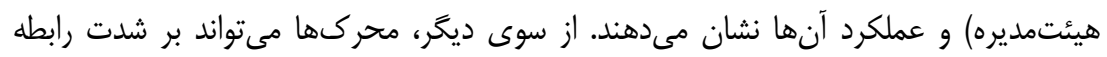

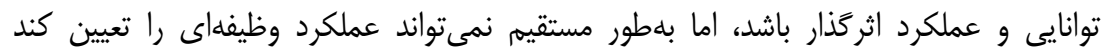

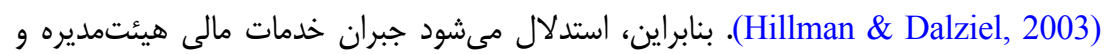
وابستخى هيئتمديره به مديرعامل و دولت بتواند اثر سرمايه فكرى هيئتمديره را بر عملكرد

نقشهاى هيئتمديره تعديل كند (شكل ऍ).
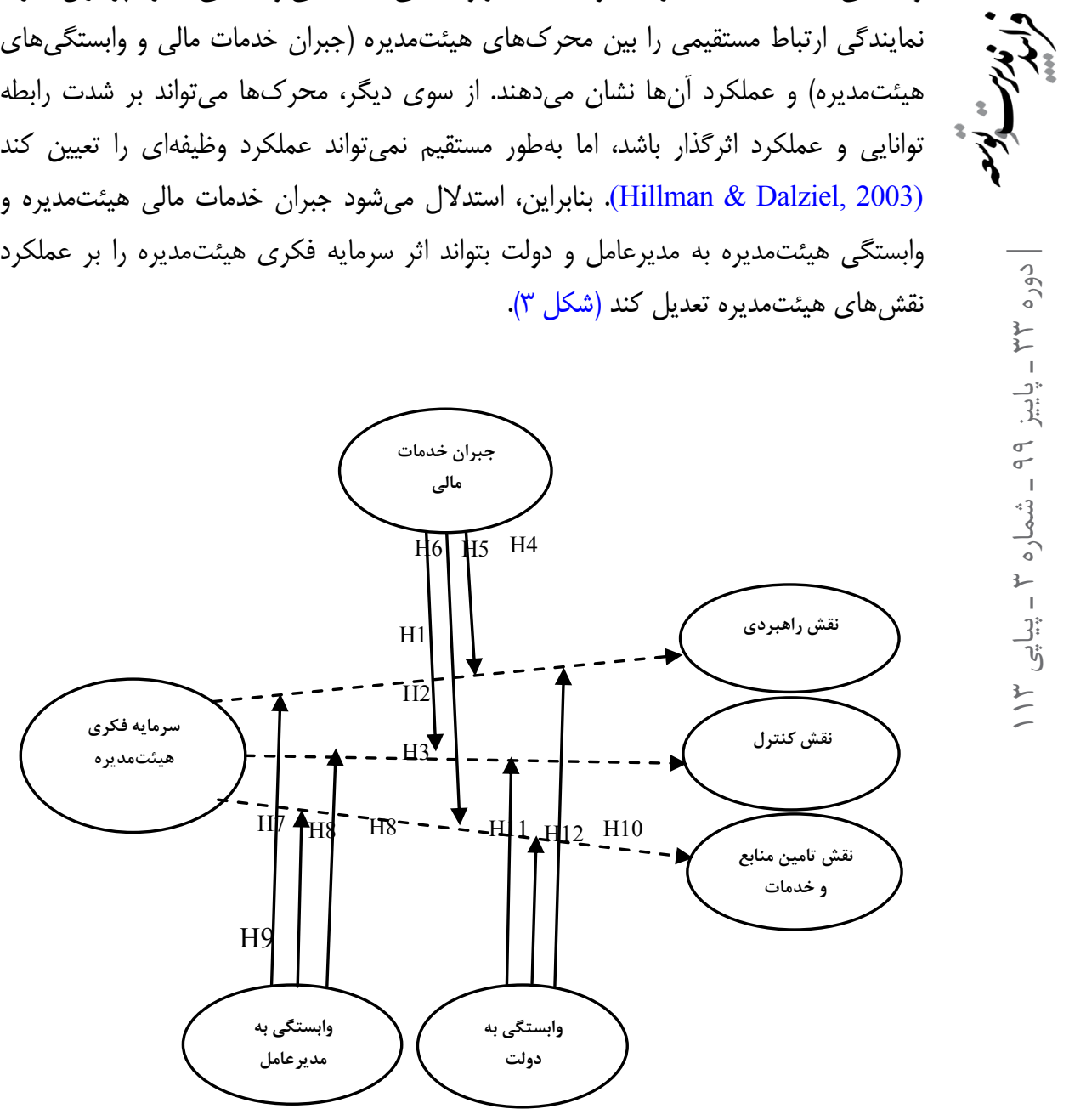

شكل "ז: مدل مفهومى يخوهش (با اقتباس از Hillman \& Dalziel, 2003 ) 


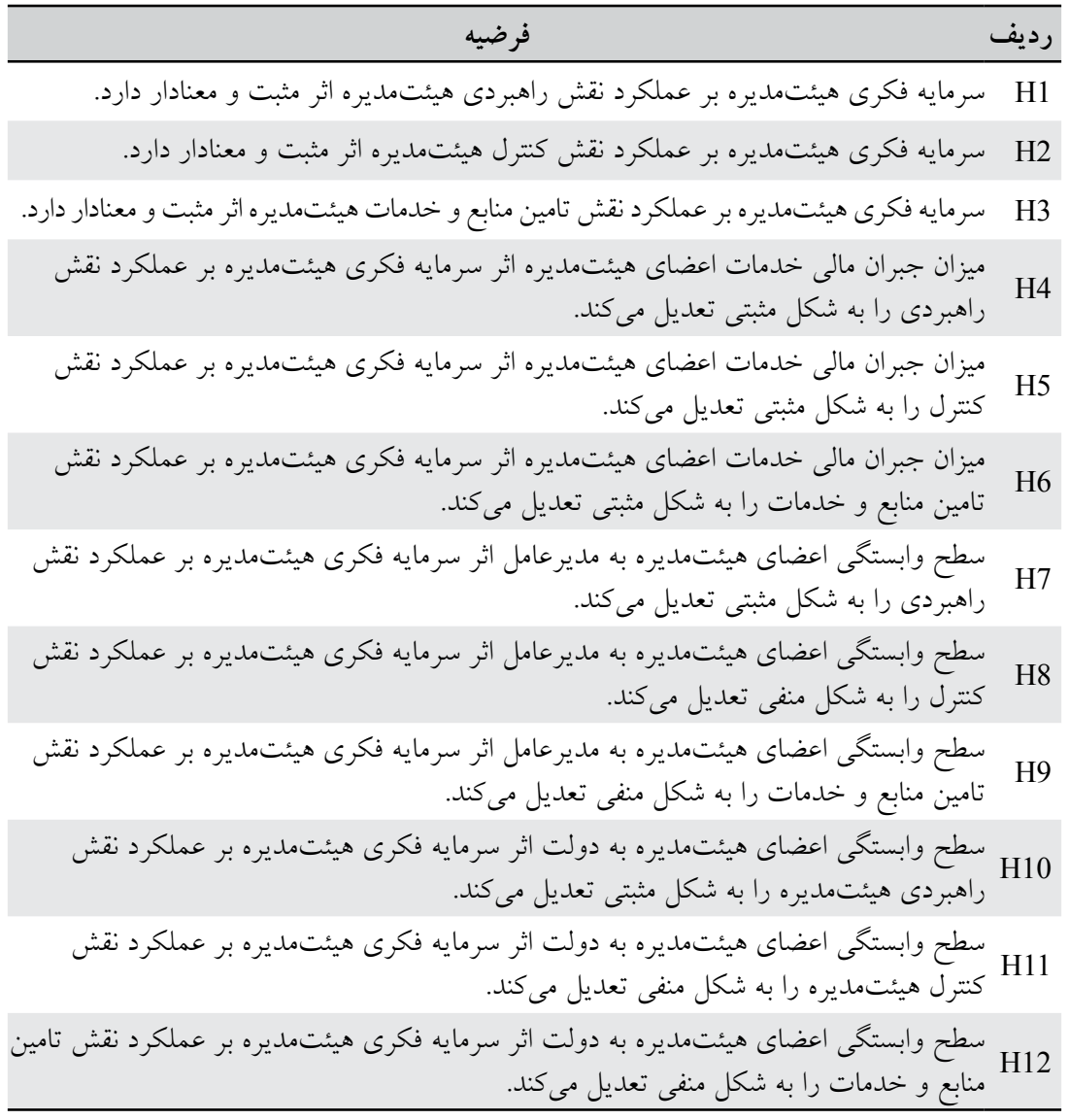

\section{روش}

يزوهش حاضر با توجه به اين كه در جستجوى دستيابى به يك هدف عملى براى تدوين راهبردهاى

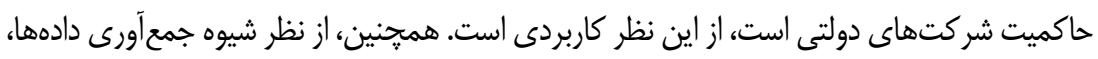
توصيفى-ييمايشى است. اين يزوهش به بررسى روابط بين متغيرها مىيردازد و در يى اثبات وجود

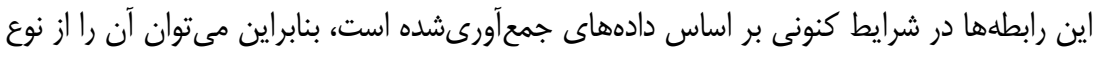
علّى طبقهبندى نمود. واحد تحليل يزوهش، سازمان (شركت) است. با لحاظ احتمال همكارى نكردن 
برخى وزارتخانهها و سازمان هاى متولى شر كتهاى دولتى در توزيع و جمع آورى يرسشنامها، در ابتدا

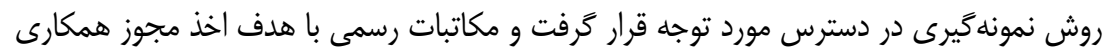

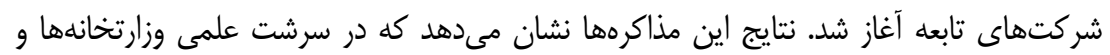

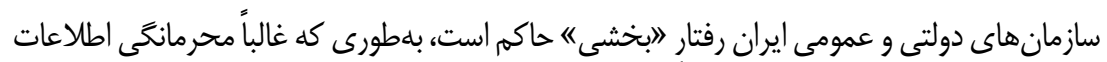

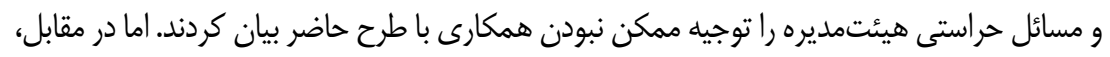

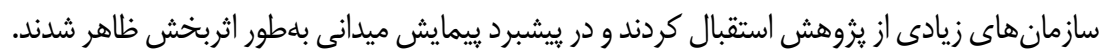

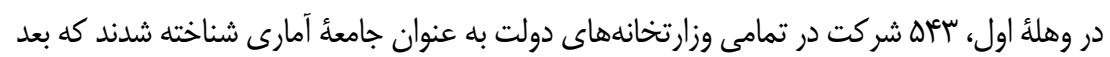

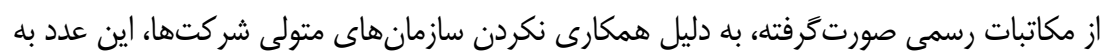

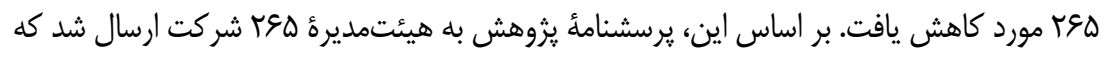

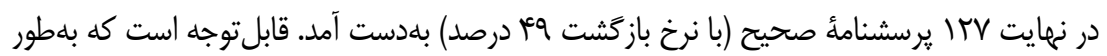

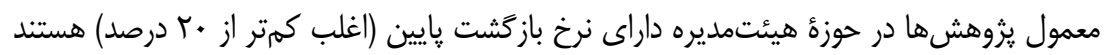
(Pettigrew, 1992; Minichilli et al., 2009) تفكيك وزارتخانه و سازمان متولى شركت نشان مىدهد.

جدول r: شر كتهاى مورد مطالعه يزووهش (به تفكيك سازمان متولى)

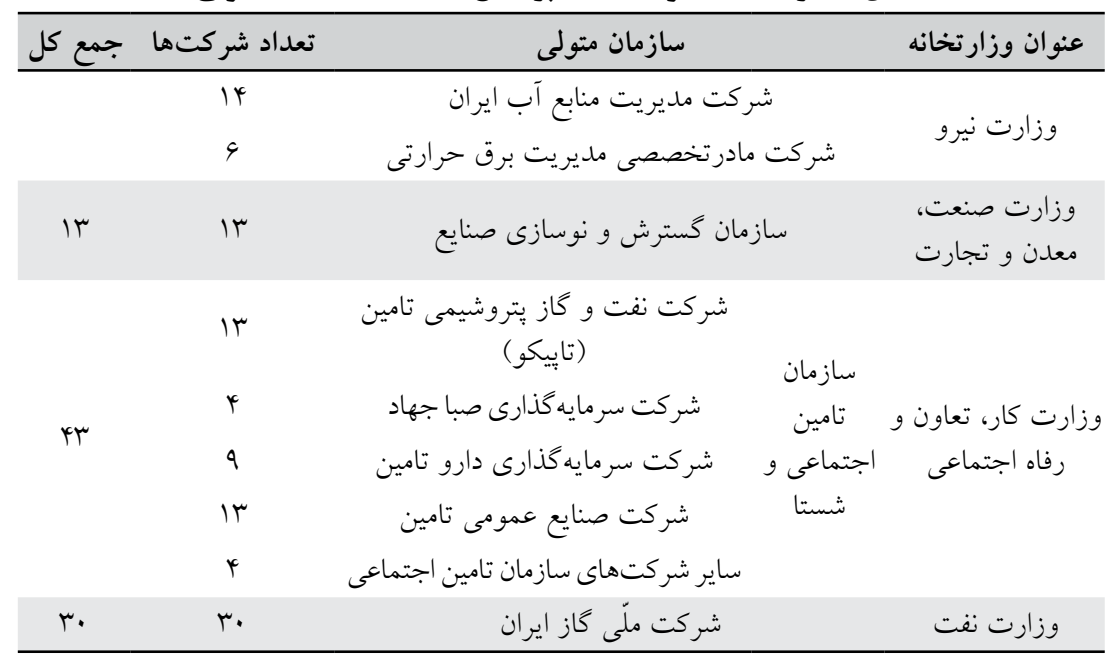

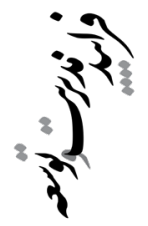

به منظور ارزيابى عملكرد هيئتمديره در مرحله اول، با الهام از يرسشنامه ماكوبيا' (عا+r)،

1. Mugobya 
يرسشنامهاى با مثأ كَويه طراحى كَديد كه در مراحل بعدى بعد از اعمال اصلاحات لازم با نظر خبركان

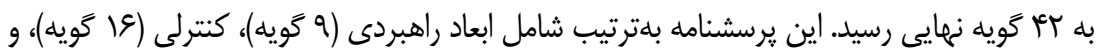

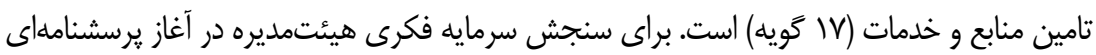

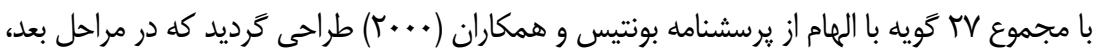

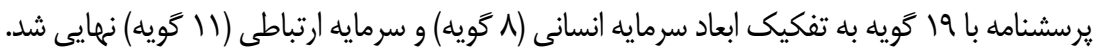

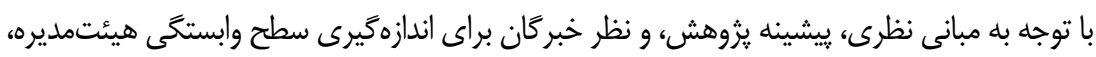

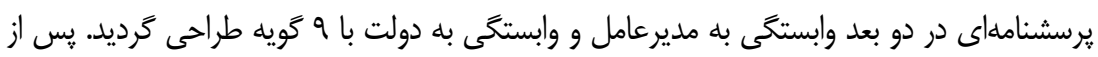

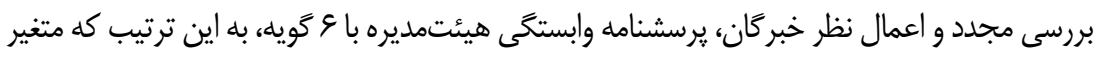

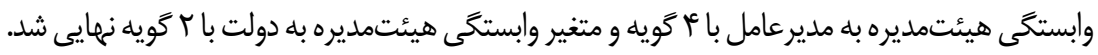

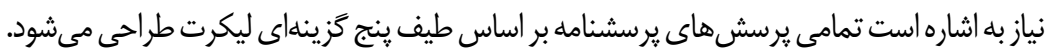

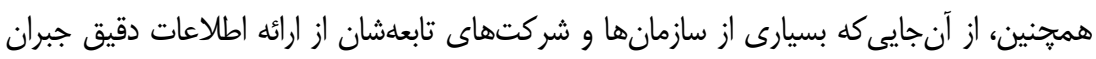

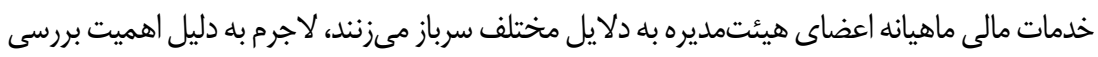

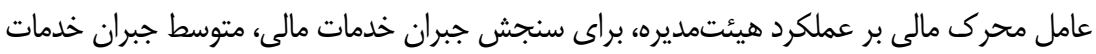

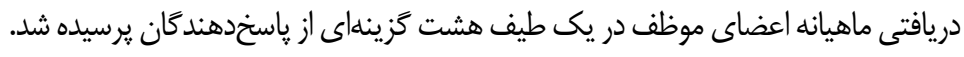

\section{آمار توصيفى متغيرها}

در اين بخش اطلاعات توصيفى متغير هاى يزوهش ارائه مىشود. جدول (ب)، اطلاعات توصيفى

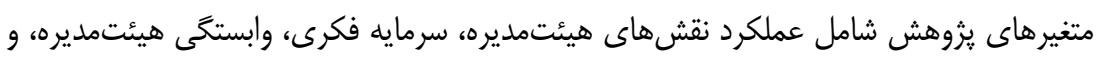

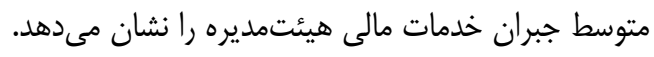

\begin{tabular}{|c|c|c|c|c|c|c|}
\hline فقدان داده & انحر اف استاندارد & بيشينه & ميانغين & ميانه & كمينه & شاخص \\
\hline · & $\cdot 191$ & 0 & $r / 9 \Lambda$ & $\mathrm{r} / \mathrm{WV}$ & $1 / 9 \mathrm{~V}$ & عملكرد نقش راهبردى \\
\hline$r$ & .199 & 0 & $r / \& V$ & r/QG & $1 / 0$ & عملكرد نقش كنترلى \\
\hline r & $\cdot 190$ & $\Delta$ & $r / 9 V$ & $r / v r$ & $1 / 94$ & عملكرد نقش تامين منابع و خدمات \\
\hline 11 & .190 & $\varphi / \wedge \Delta$ & $\mu / \uparrow \wedge$ & $\Gamma / 4 \wedge$ & $1 / 01$ & سرمايه فكرى هيئتمديره \\
\hline . & $\cdot / v$ & 0 & $r / \Delta \cdot$ & $r / \Delta \cdot$ & $1 / 1 V$ & 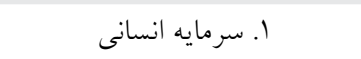 \\
\hline
\end{tabular}

ادامه جدول r: آمار توصيفى متغيرهاى يزوهش 


\begin{tabular}{|c|c|c|c|c|c|c|}
\hline فقدان داده & انحراف استاندارد & بيشينه & ميانخين & ميانه & كمينه & شاخص \\
\hline 11 & .191 & $\psi / N 1$ & r/49 & $r / F V$ & r & r. سرمايه ارتباطى \\
\hline 1 & 1 & $r / Q$ & I/VA & $1 / 0$ & 1 & و ابستخى به مديرعامل \\
\hline . & $1 / \cdot r$ & $\Delta$ & T/VT & r & 1 & و ابستخى به دولت \\
\hline . & $1 / 4 Y$ & $\wedge$ & $r / A \Delta$ & r & 1 & متوسط جبران خدمات مالى \\
\hline
\end{tabular}

\section{روش تحليل دادهها}

مدلسازى معادلههاى ساختارى به عنوان يكى از ابزارهاى قوى آمارى، بررسى ارتباطات ميان جندين

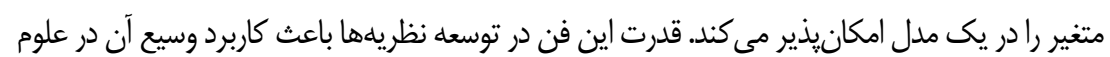

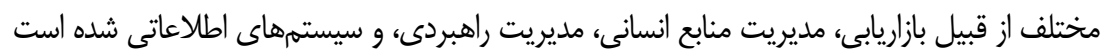

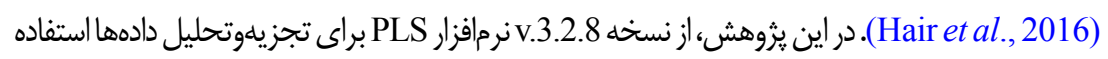

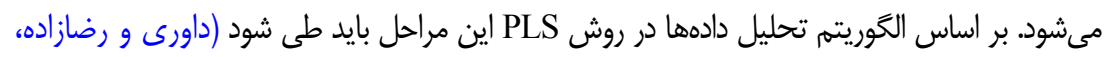

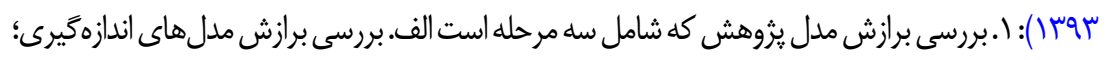

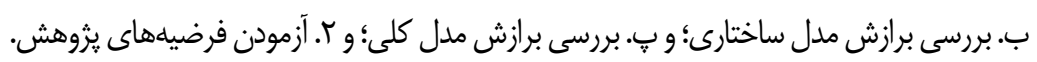

\section{برازش مدل مهاى اندازهكيرى مدل هاى انعكاسى'}

براى بررسى برازش مدلهاى اندازمّيرى شاخصهاى بايايى و روايى مورد بررسى قرار مى گيرد.

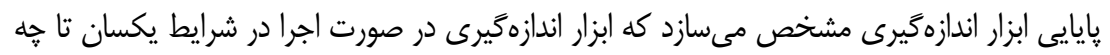

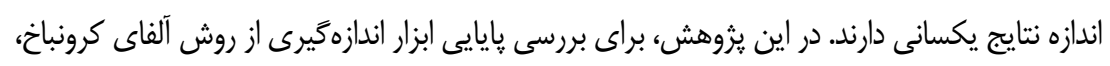

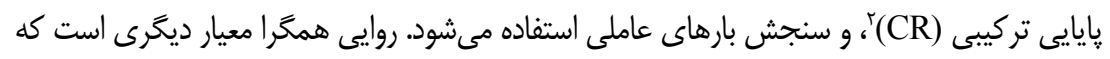

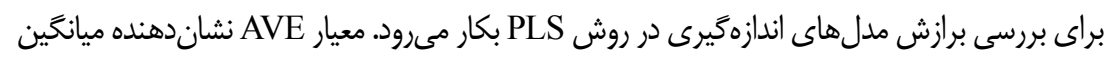

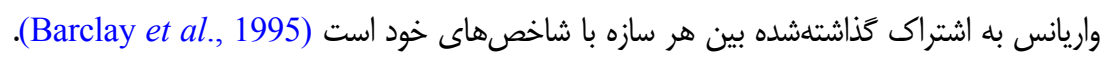

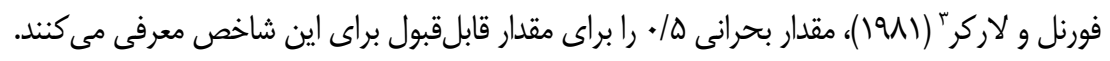

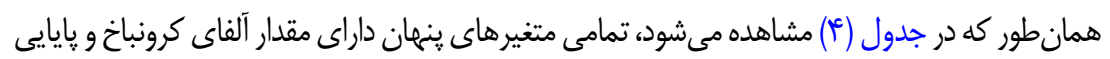
تركيبى تقريباً برابر يا بالاى V/ • هستند كه نشاندهنده اين است مدل، بايايى مناسبى دارد. همجِنين،

1. Reflective

2. Composite Reliability

3. Fornell \& Larcker 
مقدار روايى همكرا براى متغيرهاى ينهان همخى تقريباً مقدارى برابر يا بالاتر از ه/. دارند.

جدول †: كزارش شاخصهاى آلفاى كرونباخ، پايايى تركيبى، و روايى همكرا

\begin{tabular}{|c|c|c|c|}
\hline 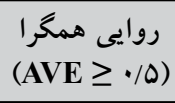 & 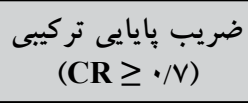 & $\begin{array}{l}\text { ضريب آلفاى كرونباخ } \\
\text { (Alpha } \geq / / V)\end{array}$ & متغير بنهان \\
\hline .191 &.$/ 94$ &.$/ 91$ & عملكرد نقش راهبردى \\
\hline$\cdot / 01$ & $\cdot / 94$ & $\cdot / 9 r$ & عملكرد نقش كتترل و نظارت \\
\hline$\cdot / 49$ & $\cdot / 94$ & . $/ 94$ & عملكرد نقش تامين منابع و خدمات \\
\hline$\cdot 109$ & $\cdot / \Lambda r$ & $\cdot / N$ & وابستخى هيئتمديره به مديرعامل \\
\hline$\cdot / v 9$ & $\cdot / 19$ & .199 & وابستكى هيئتمديره به دولت \\
\hline 1 & 1 & 1 & جبران خدمات مالى \\
\hline
\end{tabular}

در روش PLS براى بررسى روايى واگراى مدل اندازمخيرى از دو روش استفاده مىشود:

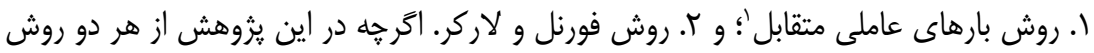

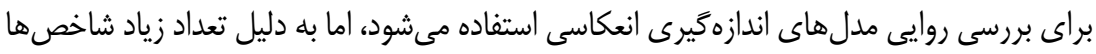

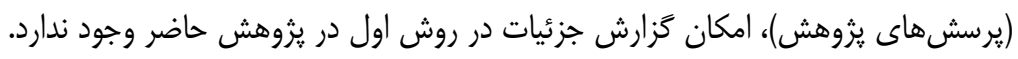

جدول ه: همبستغى هاى متغيرهاى مكنون مرتبه اول و مقادير AVE آنها

عملكرد عملكرد عملكردنقش و وابستخى و وابستخىبه جبران

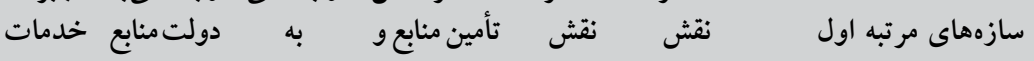

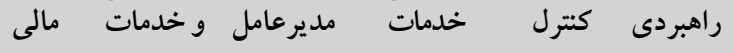

\begin{tabular}{|c|c|c|c|c|c|c|}
\hline & & & & & $\cdot / \mathrm{Vq}$ & عملكرد نقش راهبردى \\
\hline & & & & $\cdot N r$ & $\cdot / \Lambda \cdot$ & عملكرد نقش كنترل و نظارت \\
\hline & & & $\cdot / v \cdot$ & $\cdot 199$ & $\cdot / \Lambda \mid$ & عملكرد نقش تامين منابع و خدمات \\
\hline & & $\cdot / N{ }^{C}$ & $-\cdot / T$ & $-\cdot|r|$ & $-\cdot / T \varphi$ & وابستخى هيئتمديرهبه مديرعامل \\
\hline & $\cdot / \mathrm{AV}$ & $\cdot \pi$ & $-\cdot / 1 r$ & $-\cdot / 19$ & $-\cdot / r_{r}$ & وابستخى هيئتمديره به دولت \\
\hline 1 &.$/ \cdot 4$ & $\cdot / 1 r$ & $-\bullet / \cdots \wedge$ & $.1 \cdot 0$ & $-\cdot / \cdot 4$ & جبران خدمات مالى \\
\hline
\end{tabular}

به بيان فورنل و لاركر (1911)، روايى واكرا وقتى در سطح قابلقبولى است كه ميزان جذر

1. Cross-Loadings 
AVE براى هر سازه از واريانس اشتراكى بين آن سازه و سازههاى ديخر بيشتر باشد. همان كونه

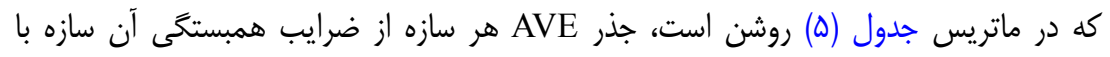

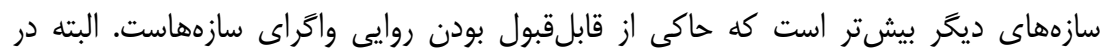
دو سازه (عملكرد نقش كنترل و نظارت، و عملكرد نقش تامين منابع و خدمات)، مقدار واريانس

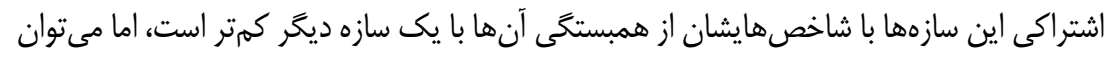

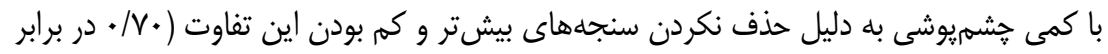

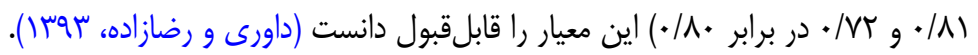

\section{برازش مدلهاى اندازهكيرى مدل هاى سازنده'}

در يزوهش حاضر دو سازه سر مايه انسانى و سرمايه ارتباطى هيئتمديره به عنوان متغير هاى سازنده

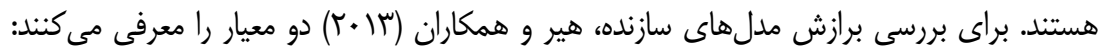
معنادارى بارهاى عاملى شاخصها از طريق T-values؛ و بررسى همخطى بين شاخصها: (يرسشهارها).

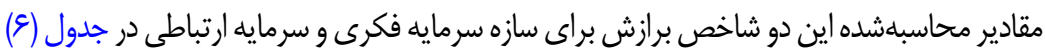

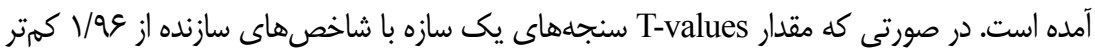

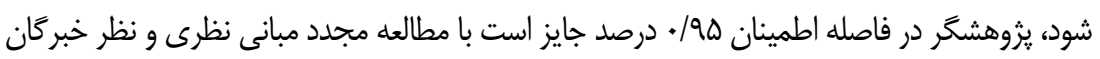

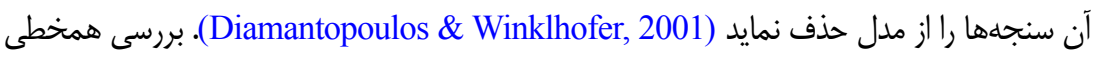

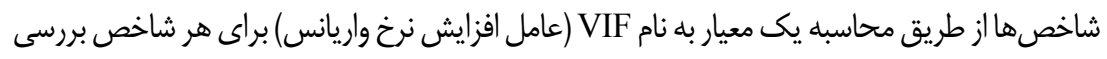

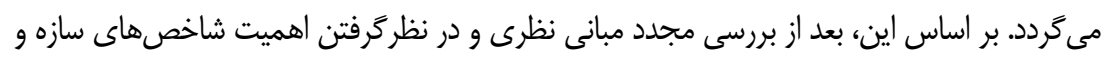

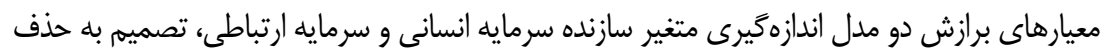
تعدادى شاخص كرفته شد جدول (9). 
جدول \&: كزارش معيارهاى برازش مدل اندازهيرى سازنده سرمايه فكرى

\begin{tabular}{|c|c|c|c|c|c|}
\hline نتيجه برازش شاخص & VIF & مقدار ويزٔه T & بار عاملى & شاخص & سازه \\
\hline حذف & $r / r$. & $\cdot / T r$ & $\cdot 1 \cdot r q$ & EnsCapitall & \multirow{8}{*}{$\begin{array}{c}3 \\
3 \\
\frac{3}{3} \\
3 \\
3 \\
3 \\
3 \\
3 \\
3 \\
3\end{array}$} \\
\hline حفظ & $T / T_{G}$ & $\cdot / \pi q$ & $\cdot / \cdot r \Lambda$ & EnsCapital2 & \\
\hline حفظ & $r / \Lambda$ & $r / l$. & $\cdot / \mu$ & EnsCapital3 & \\
\hline حفظ & $T / \Delta \Lambda$ & $T / 9$. & $\cdot \pi \cdot$ & EnsCapital4 & \\
\hline حفظ & $r / 11$ & $1 / \pi$. &.$/ 11$ & EnsCapital5 & \\
\hline حفظ & $r / T$ & $4 / 01$ & . /Qr & EnsCapital6 & \\
\hline حفظ & $\mu / \cdot 0$ & $1 / \cdot r$ &.$- / 11$ & EnsCapita7 & \\
\hline حذف & $1 / 00$ & • & $\cdot / \cdot 1$ & EnsCapital8 & \\
\hline حفظ & $r / \mu q$ & $r / N I$ & $\cdot / 1 \wedge$ & ErtCapMosh1 & \multirow{11}{*}{$\begin{array}{c}3 \\
3 \\
\frac{3}{2} \\
\frac{3}{3} \\
-1 \\
3 \\
3 \\
3 \\
3 \\
3 \\
0\end{array}$} \\
\hline حذف & $r / \wedge 9$ & $\cdot 19$ & $\cdot / \cdot 0$ & ErtCapTamin 1 & \\
\hline حفظ & $T / 99$ & $1 / 9 V$ & $\cdot / \wedge$ & ErtCapTamin2 & \\
\hline حفظ & $r / 91$ & $1 / 19$ & .119 & ErtCapKarkn & \\
\hline حفظ & $r / r q$ & $T / \mu$ & $\cdot / T Y$ & ErtCapRoghba2 & \\
\hline حذف & $1 / 4 x$ & $\cdot / \wedge 1$ &.$/ .9$ & ErtCapRoghba3 & \\
\hline حفظ & TNY & $1 / \wedge$ & $\cdot / r$. & ErtCapEjt2 & \\
\hline حذف & $1 / 11$ & $\cdot / r 1$ & $-\cdot / \cdot r$ & ErtCapMdia2 & \\
\hline حفظ & $1 / 29$ & $4 / 9 Y$ & $\cdot / 4$ & ErtCapGov1 & \\
\hline حذف & $1 / 01$ & . /Qr & $-\cdot / \cdot 4$ & ErtCapGov2 & \\
\hline حفظ & $1 / \cdot V$ & $r / 9 \Lambda$ & $\cdot / I V$ & ErtCapNCov & \\
\hline
\end{tabular}

\section{برازش مدل ساختارى}

״ِ از بررسى روايى و يايايى مدلهاى اندازهيرى، مدل ساختارى از طريق روابط بين متغيرهاى مكنون

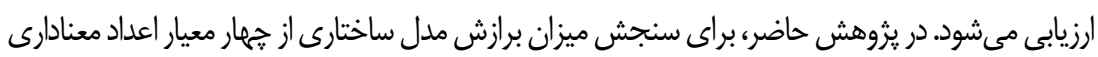

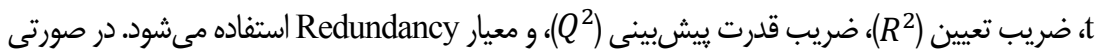
كه مقدار th از عه/ بيشتر شود، نشان از صحت رابطه بين سازهها و در نتيجه تاييد فرضيدهاى يزوهش 


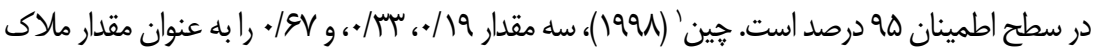
براى مقادير ضعيف، متوسط، و قوى R معرفى مى كند. بر اساس اين، با توجه به نتايج (جدول V) مقادير

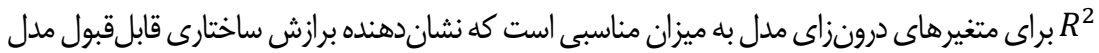

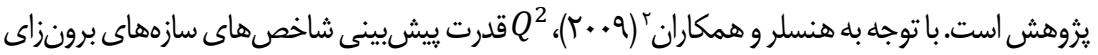
مدل يثوهش بلهنسبت قوى است، بنابراين از اين طريق برازش ساختارى مدل يثوهش تاييد مىشود. Redundancy

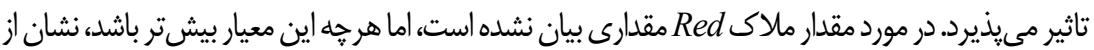
برازش مناسبتر بخش ساختارى مدل يزوهش است.

جدول ץ: كزارش معيارهاى برازش مدل ساختارى Red

\begin{tabular}{|c|c|c|c|}
\hline Red & $Q^{2}$ & $R^{2}$ & سازههاى مكنون \\
\hline$\cdot / 0 \mathrm{~V}$ & $\cdot / 4$ & $\cdot / 99$ & سرمايه فكرى هيئتمديره \\
\hline$\cdot / \mu_{q}$ & $\cdot / \pi \Delta$ & $\cdot 190$ & اثربخشى نقش راهبردى \\
\hline$\cdot / \mu 1$ & $\cdot / r \Lambda$ & $\cdot 194$ & اثربخشى نقش كنترل و نظارت \\
\hline$\cdot / 44$ & $\cdot / \mu 1$ & $\cdot / v$ & اثربخشى نقش تامين منابع و خدمات \\
\hline
\end{tabular}
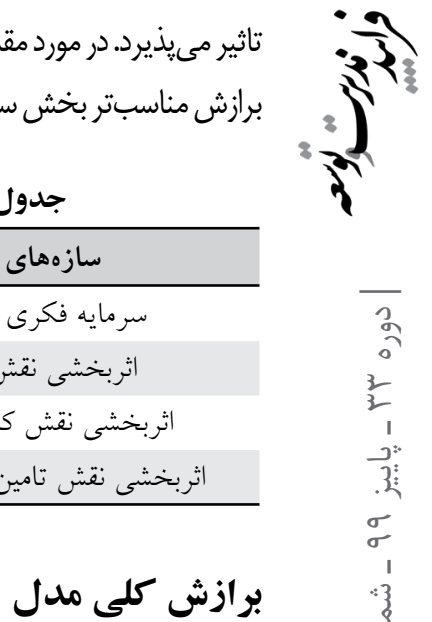

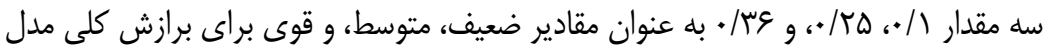
معرفى مىشوند. مقدار وع/• نشان از برازش كلى بسيار قوى مدل يثوهش است.

\section{آزمون فرضيههاى بزوهش}

مطابق با الخوريتم تحليل دادهها در روش PLS يس از بررسى برازش مدلهاى اندازهگيرى،

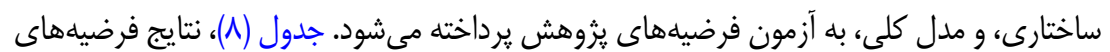
يزوهش را نشان مى دهد.

1. Chin

2. Henseler et al. 
جدول ᄉ: نتايج فرضيههاى مدل معادلههاى ساختارى يثووه

\begin{tabular}{|c|c|c|c|}
\hline نتايج & آماره T & ض استاندارد & فرضيهها \\
\hline تاييد & $1 r / \Delta \Lambda$ & 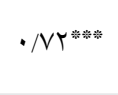 & و و. سعنادار دارد. فكرى هيئتمديره بر عملكرد نقش راهبردى هيئتمديره اثر مثبت \\
\hline تاييد & $1 \pi / V \pi$ & $\cdot / N^{* * * *}$ & معنادار دارد. سمايه فكرى هيئتمديره بر عملكرد نقش كنترل هيئتمديره اثر مثبت و \\
\hline تاييد & $r Q / 9 \Lambda$ & •/A & اثر مثبت و معايه فكرى هيئتمديره برد بر عملكرد نقش تامين منابع و خدمات هيئتمديره \\
\hline رد & $1 / 9$. & -.1 .9 & 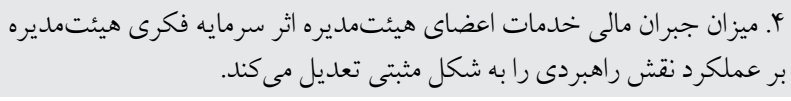 \\
\hline رد & $1 / N V$ & $-.1 \cdot 9$ & 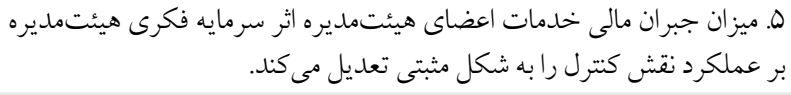 \\
\hline رد & $\cdot / 49$ & $-\cdot / \cdot r$ & 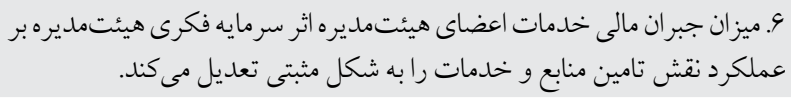 \\
\hline تاييد & $4 / \cdot 0$ & $\cdot / 19^{* *:}$ & 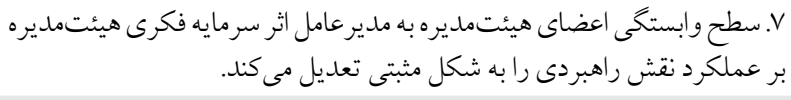 \\
\hline رد & $\cdot / 9 V$ & $\cdot / \cdot \wedge$ & 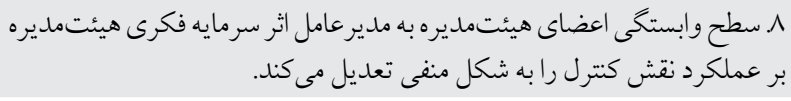 \\
\hline נد & $\cdot / 49$ & $-\cdot / \cdot r$ & 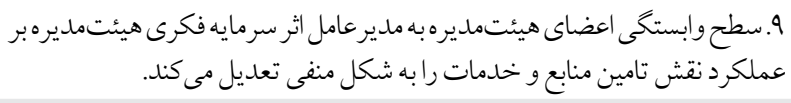 \\
\hline رد & $\cdot / \cdot \Lambda$ & $-\cdot / \cdot r$ & 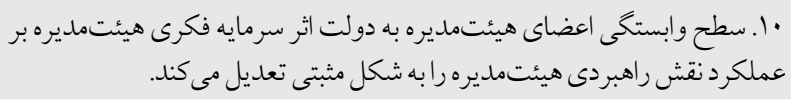 \\
\hline تاييد & T/R & $-\cdot / / \mu \Delta^{* * * *}$ & 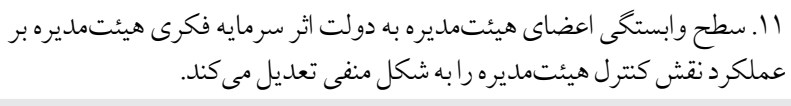 \\
\hline נد & $\cdot|\wedge|$ & $-\cdot / \cdot r$ & 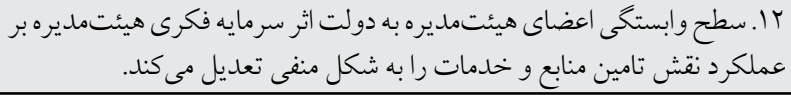 \\
\hline
\end{tabular}

\section{بحث و نتيجه تيرى}

يثوهش حاضر با هدف توسعه يكى مدل مفهومى جديد با قابليت آزمون كمّى انجام شده است.

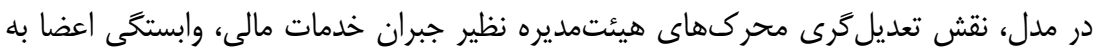

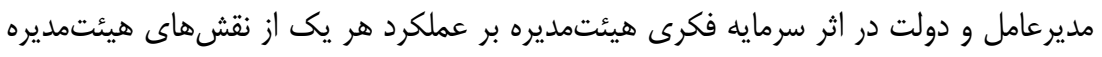


در شركتهاى دولتى مورد ارزيابى قرار كرفته است.

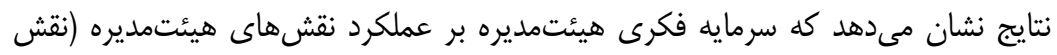

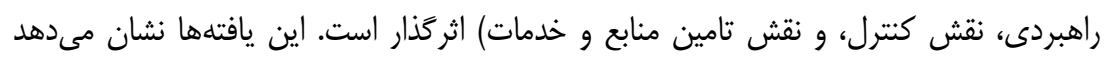
هيئتمديرهها با سرمايه فكرى بيشتر، تصميمهاى راهبردى بهترى مى كيرند، كنترل قوى نترى برى

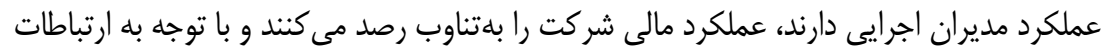

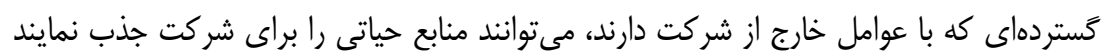

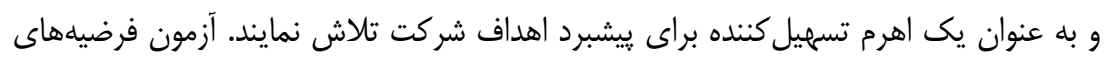

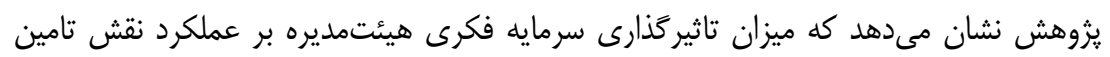

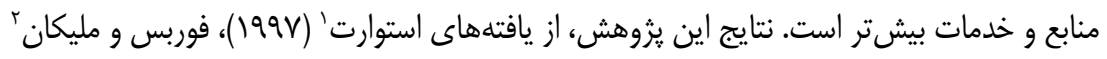

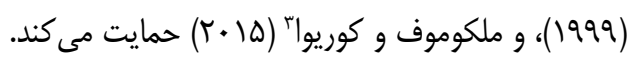

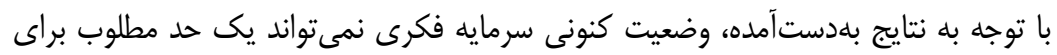

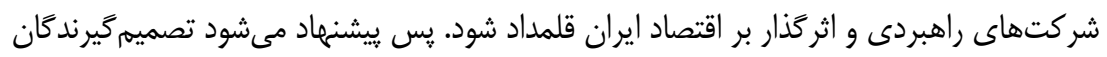

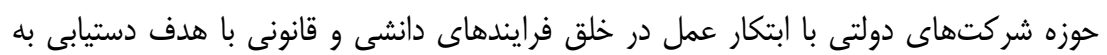

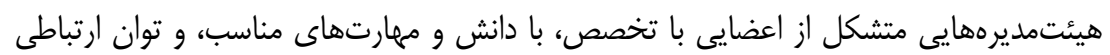

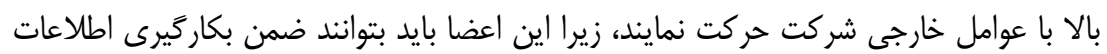

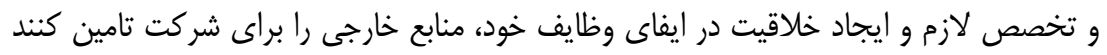

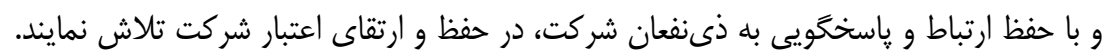

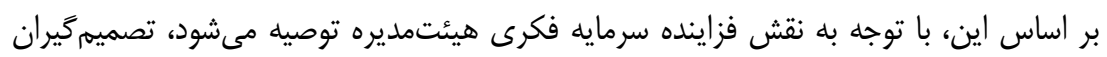

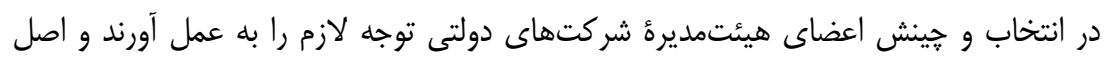

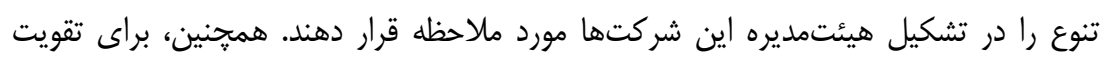

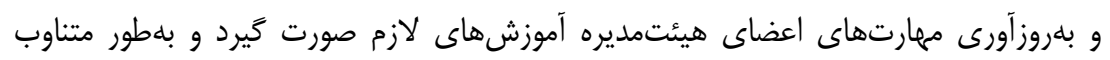

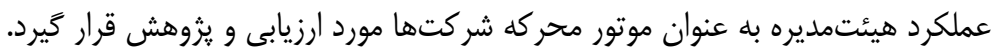

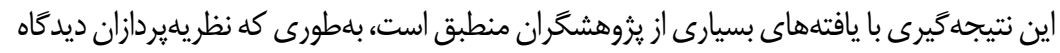

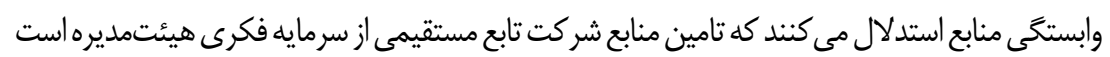

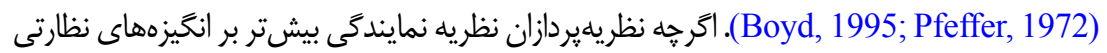

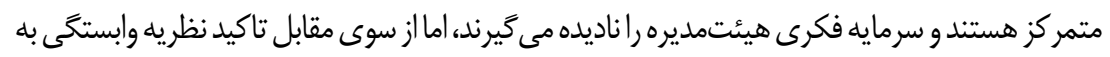

1. Stewart

2. Forbes \& Milliken

3. Melkumov \& Khoreva 
منابع بيشتر بر سرمايه هيئتمديره است. بر اساس اين، سر مايه هيئتمديره به معناى توانيايى هيئتمديره

براى تامين منابع به شركت در نظركَرفته مي شود (Hillman \& Dalziel, 2003).

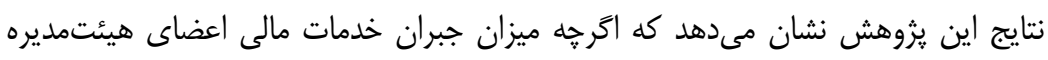

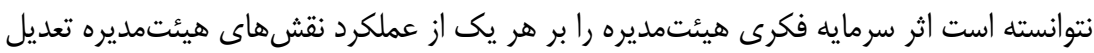

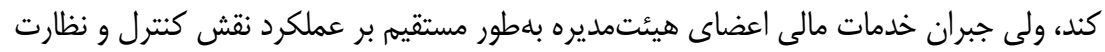

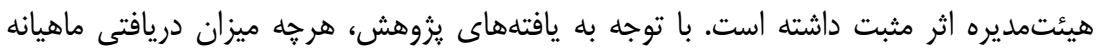

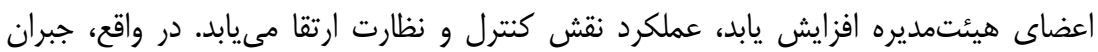

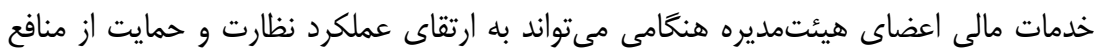

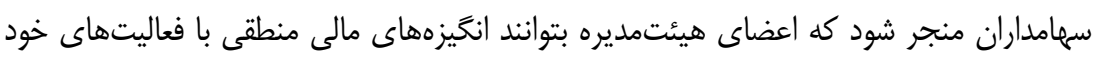

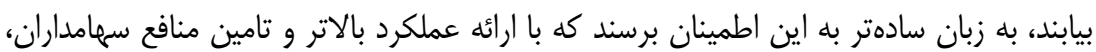

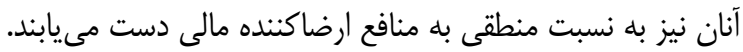

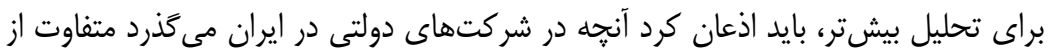

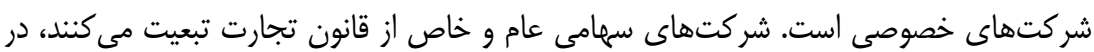

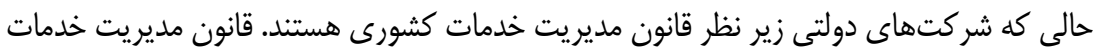

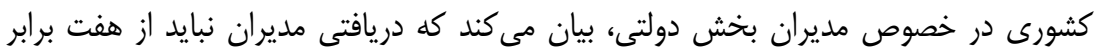

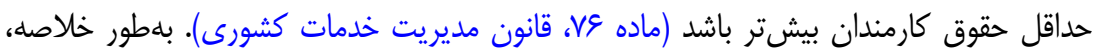

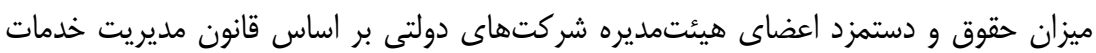

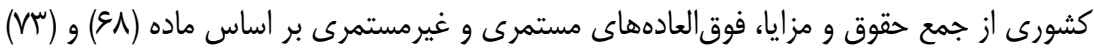

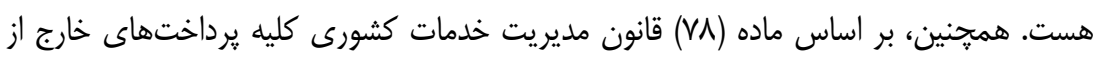

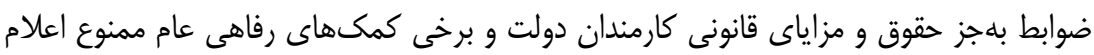

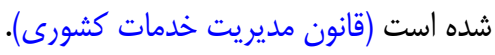

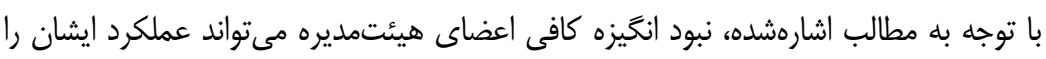

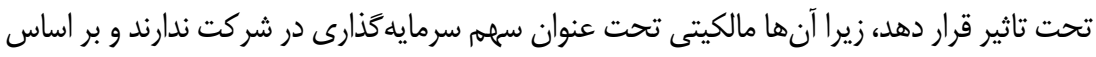

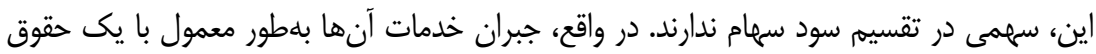

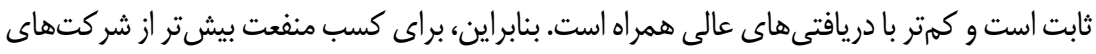

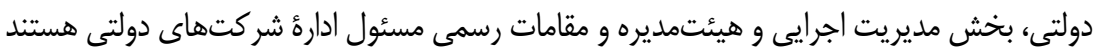

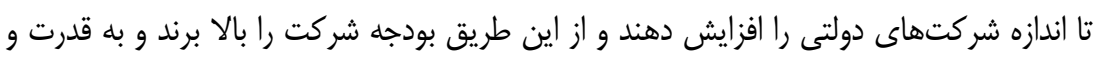

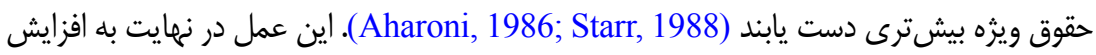


هزينه كل دولت، تخصيص ناكارامد ثروت در ميان شر كتهاى دولتى، و توليد ناكارا منجر مى شود.

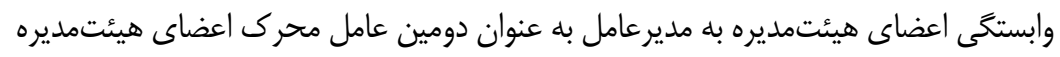

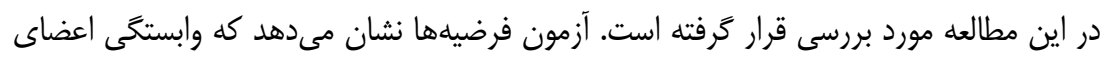
هيئتمديره به مديرعامل اثر سرمايه فكرى هيئتمديره بر عملكرد نقش راهبردى هرئ هيئتمديرها را تعديل و تقويت كرده است. از سوى ديكر، بررسى نوع متغير تعديل

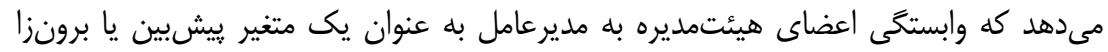

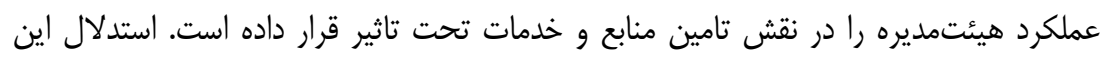

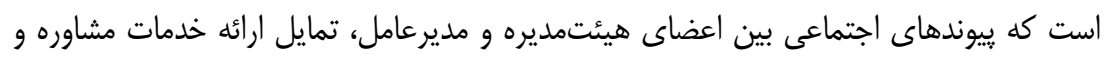

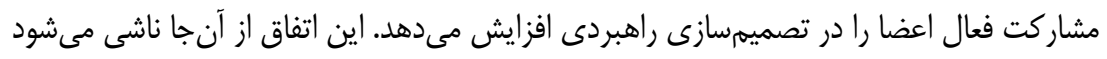

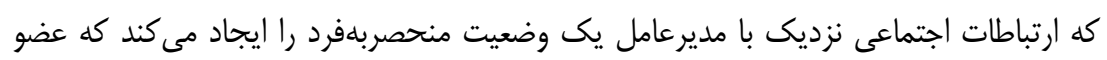

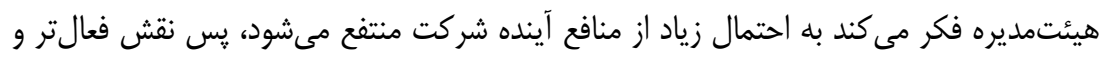

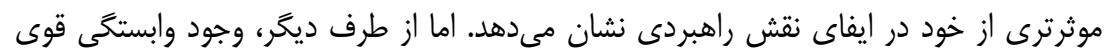

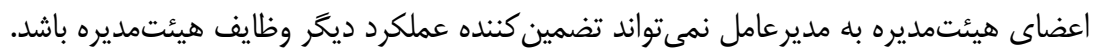

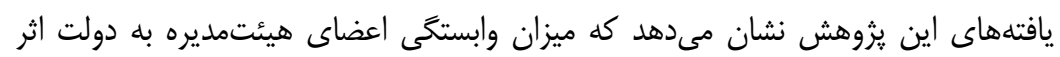

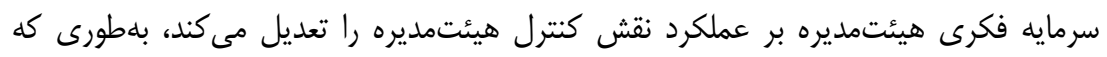

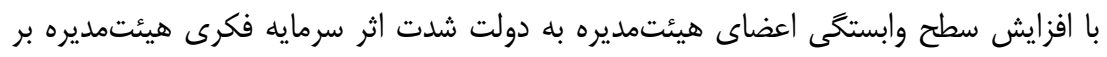

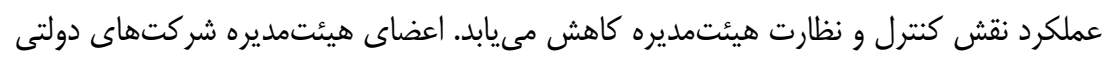

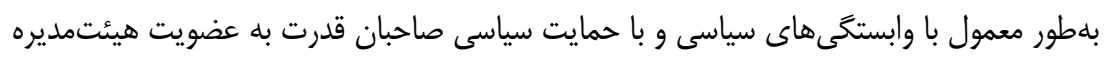

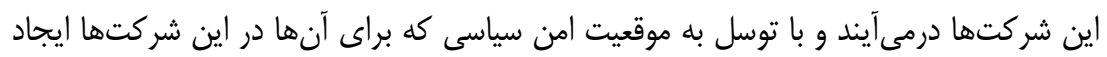

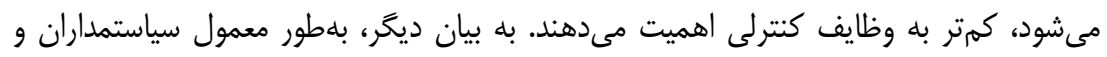

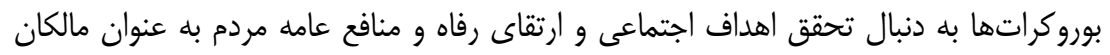

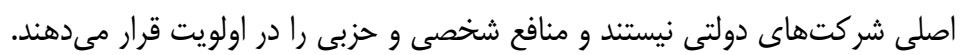

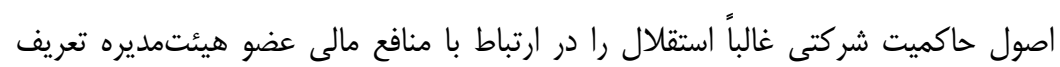

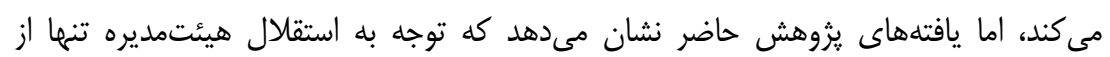

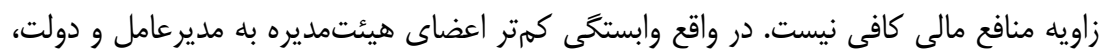
نشاندهنده استقال بيشتر اعضاى هيئتمديره از نظر سياسى، اجتماعى، و و عاطفى است.

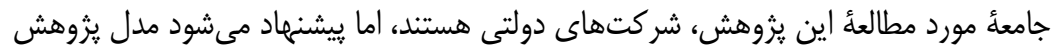

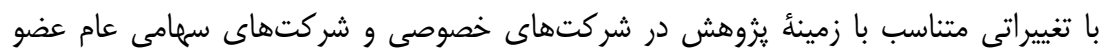


سازمان بورس و اوراق بهادار نيز مورد آزمون قرار كيرد. با توجه به اهميت ارزيابى اثربخشى هيئتمديره و عملكرد مالى شركتها به عنوان خروجى عملكرد نقشهاى هيئتمديره بيشنهاد

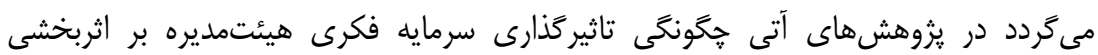
هيئتمديره و عملكرد مالى شر كت مورد مطالعه قرار كيرد.

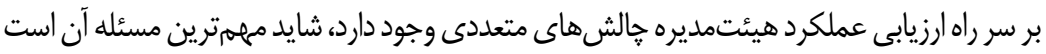
كه هيج كس بلهغير از خود هيئتمديره نمىتواند آن را انجام دهد (Minichilli et al., 2009)، كه يكى

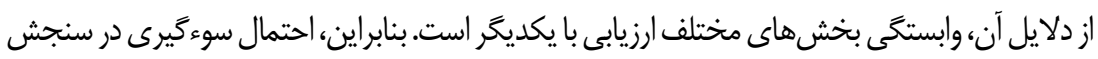

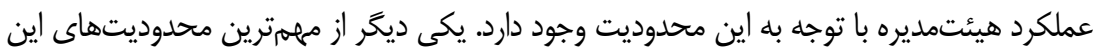

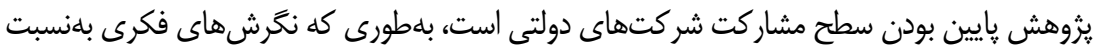

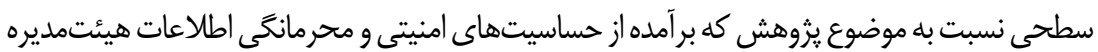

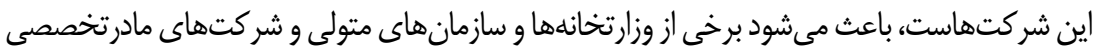

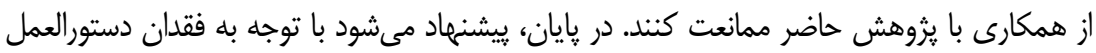

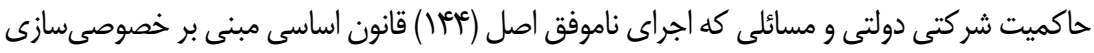

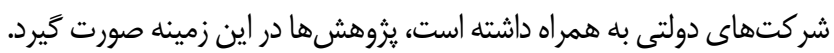

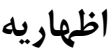

اين يزوهش از سوى موسسه عالى آموزش و يزوهش مديريت و برنامهريزى حمايت مالى شده است. در اينجا از معاونت يُوهشى موسسه براى حمايت مالى و ساير اقدامهايى كه انجام اين يزوهش را تسهيل كرده است، تشكر و قدردانى مى گردد.

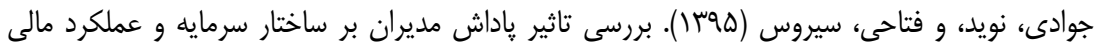

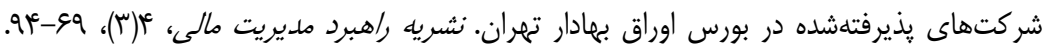

10.22051/jfm.2016.2573

داورى، على، و رضازاده، آرش (سوسج). ملسازى معادلات ساختارى با نرو/فزار PLS. سازمان انتشارات

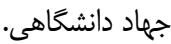


دهقان هراتى، شهين؛ فاضل يزدى، على؛ جبارى، حسين، و اسديور، احمدعلى (بوس (). بررسى رابطه سرمايه

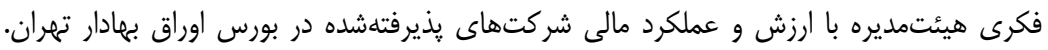

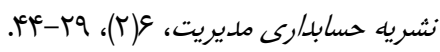

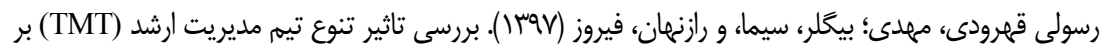

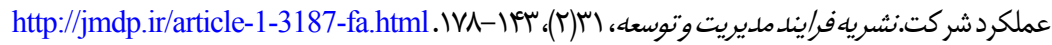

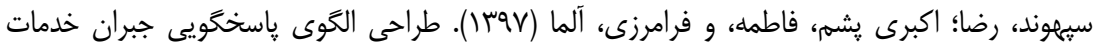

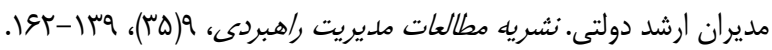

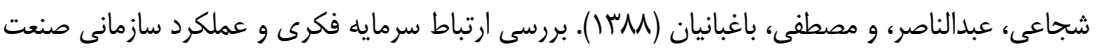

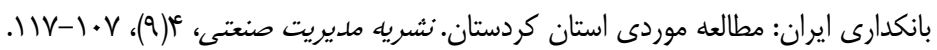

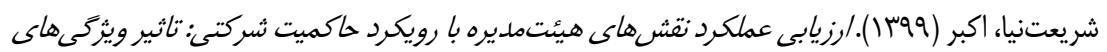

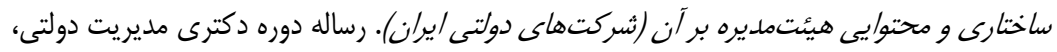

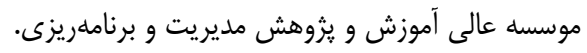

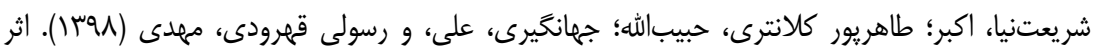

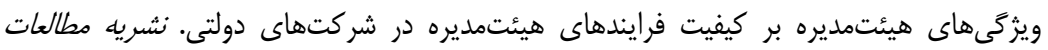

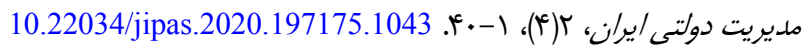

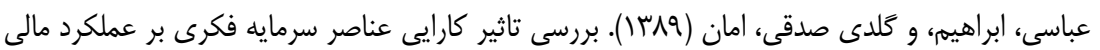

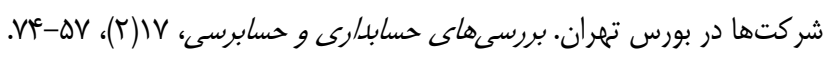

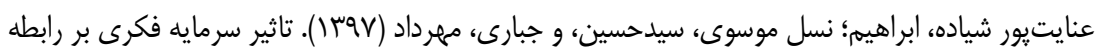

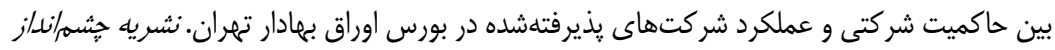

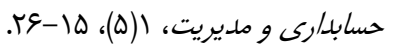

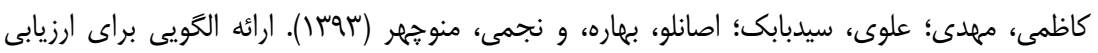

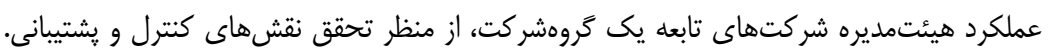

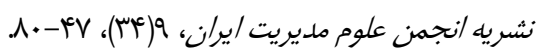

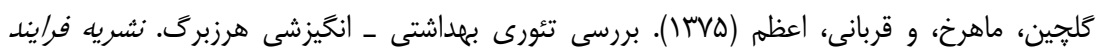

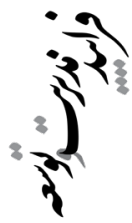

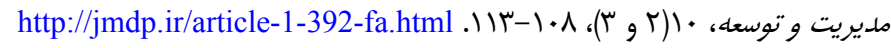

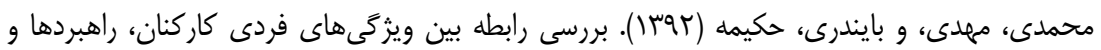

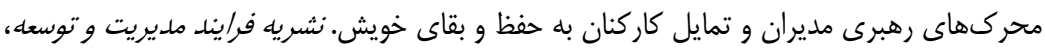

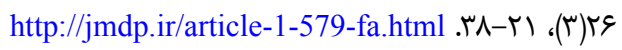
نيكو اقبال، علىاكبر (عوسا). مصيبت شركتهاى دولتى و شبهدولتى در ايران و حكمرانى خوب. نشريه

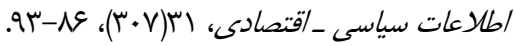


Adams, R. B. (2012). Governance and the Financial Crisis. International Review of Finance, 12(1), 7-38. https://doi.org/10.1111/j.1468-2443.2011.01147.x

Aharoni, Y. (1986). The Evolution and Management of State Owned Enterprises: Ballinger Publishing Company.

Anderson, C., \& Anthony, R. (1986). The New Corporate Directors: John Wiley \& Sons.

Andrews, W. A. \& Dowling, M. J. (1998). Explaining Performance Changes in Newly Privatized Firms. Journal of Management Studies, 35(5), 601-617. https://doi.org/10.1111/1467-6486.00111.

Anthony, R. N. (1965). Planning and Control Systems: A Framework for Analysis [by]. Division of Research. Graduate School of Business Administration, Harvard University.

Barclay, D., Higgins, C., \& Thompson, R. (1995). The Partial Least Squares (PLS) Approach to Causal Modeling: Personal Computer Adoption and Use as an Illustration. Technology Studies, 2(2), 285-309.

Barontini, R., \& Bozzi, S. (2011). Board Compensation and Ownership Structure: Empirical Evidence for Italian Listed Companies. Journal of Management \& Governance, 15(1), 59-89.

Barton, D., \& Wong, S. (2006). Improving Board Performance in Emerging Markets. McKinsey Quarterly, 1(1), 35-43.

Berezinets, I., Garanina, T., \& 1lina, Y. (2016). Intellectual Capital of a Board of Directors and Its Elements: Introduction to the Concepts. Journal of Intellectual Capital, 17(4), 632-653. https://doi.org/10.1108/JIC-01-2016-0003.

Bontis, N., Keow, W. C. C., \& Richardson, S. (2000). Intellectual Capital and Business Performance in Malaysian Industries. Journal of Intellectual Capital, 1(1), 85-100. https://doi.org/10.1108/14691930010324188.

Boyd, B. (1995). CEO Duality and Firm Performance:AContingency Model. Strategic Management Journal, 16(4), 301-312. https://doi.org/10.1002/smj.4250160404.

Burt, R. S. (1980). Co-optive Corporate Actor Networks: A Reconsideration of Interlocking Directorates Involving American Manufacturing. Administrative Science Quarterly, 25(4), 557-582. https://doi.org/10.2307/2392281.

Chin, W. W. (1998). The Partial Least Squares Approach to Structural Equation Modeling. Modern Methods for Business Research, 295(2), 295-336.

Dalton, D. R., Daily, C. M., Ellstrand, A. E., \& Johnson, J. L. (1998). MetaAnalytic Reviews of Board Composition, Leadership Structure, and Financial Performance. Strategic Management Journal, 19(3), 269-290. https://doi.org/10.1002/(SICI)1097-0266(199803)19:3<269::AID-SMJ950>3.0.CO;2-K.

Diamantopoulos, A., \& Winklhofer, H. M. (2001). Index Construction with 
Formative Indicators: An Alternative to Scale Development. Journal of Marketing Research, 38(2), 269-277. https://doi.org/10.1509/jmkr.38.2.269.18845.

Doucouliagos, H., Haman, J., \& Askary, S. (2007). Directors' Remuneration and Performance in Australian Banking. Corporate Governance: An International Review, 15(6), 1363-1383. https://doi.org/10.1111/j.1467-8683.2007.00651.x.

Emerson, R. M. (1962). Power-Dependence Relations. American Sociological Review, 27(1), 31-41. https://doi.org/10.2307/2089716.

Firth, M., Fung, P. M., \& Rui, O. M. (2006). Corporate Performance and CEO Compensation in China. Journal of Corporate Finance, 12(4), 693-714. https://doi.org/10.1016/j.jcorpfin.2005.03.002.

Forbes D.P., Milliken F. (1999). Cognition and Corporate Governance: Understanding Board of Directors as Strategic DecisionMaking Groups. Academy of Management Review. 24(3), 489-505. https://doi.org/10.5465/amr.1999.2202133.

Fornell, C., \& Larcker, D. F. (1981). Evaluating Structural Equation Models with Unobservable Variables and Measurement Error. Journal of Marketing Research, 18(1), 39-50. https://doi.org/10.1177/002224378101800104.

Gabrielsson, J., Huse, M., \& Minichilli, A. (2007). Understanding the Leadership Role of the Board Chairperson Through a Team Production Approach. International Journal of Leadership Studies, 3(1), 21-39.

Gulati, R., \& Westphal, J. D. (1999). Cooperative or Controlling? The Effects of CEO-Board Relations and the Content of Interlocks on the Formation of Joint Ventures. Administrative Science Quarterly, 44(3), 473-506. https://doi.org/10.2307/2666959.

Hair Jr, J. F., Hult, G. T. M., Ringle, C., \& Sarstedt, M. (2016). A Primer on Partial Least Squares Structural Equation Modeling (PLS-SEM) Sage Publications. Thousand Oaks, CA, USA.

Hansell, C. (2003). What Directors Need to Know: Corporate Governance: Thomson Carswell.

Henseler, J., Ringle, C. M., \& Sinkovics, R. R. (2009). The Use of Partial Least Squares Path Modeling in International Marketing, New Challenges to International Marketing: Emerald Group Publishing Limited. https://doi.org/10.1108/S1474-7979(2009)0000020014.

Hillman, A. J., \& Dalziel, T. (2003). Boards of Directors and Firm Performance: Integrating Agency and Resource Dependence Perspectives. Academy of Management Review, 28(3),383-396. https://doi.org/10.5465/amr.2003.10196729.

Hsu, Y. H., \& Fang, W. (2009). Intellectual Capital and New Product Development Performance: The Mediating Role of Organizational Learning Capability. Technological Forecasting and Social Change, 76(5), 664-677. https://doi.org/10.1016/j.techfore.2008.03.012. 
Hughes, J. J. (1996). The Greenbury Report on Directors' Remuneration. International Journal of Manpower, 17(1), 4-9. https://doi.org/10.1108/01437729610110585.

Hung, H. (1998). A Typology of the Theories of the Roles of Governing Boards. Corporate Governance: An International Review, 6(2), 101-111.

Huse, M. (2007). Boards, Governance and Value Creation: The Human Side of Corporate Governance: Cambridge University Press.

Johnson, J. L., Daily, C. M. \& Ellstrand, A. E. (1996) Boards of Directors: A Review and Research Agenda. Journal of Management, 22(3), 409-438. https://doi.org/10.1177/014920639602200303.

Kazan, E. (2016). The Impact of CEO Compensation on Firm Performance in Scandinavia. (8th IBA Bachelor Thesis Conference), University of Twente.

Kiel, G. C., \& Nicholson, G. J. (2003). Board Composition and Corporate Performance: How the Australian Experience Informs Contrasting Theories ofCorporate Governance. Corporate Governance:AnInternational Review, 11(3), 189-205. https://doi.org/10.1111/1467-8683.00318.

Levrau, A., \& Van Den Berghe, L. (2007). Corporate Governance and Board Effectiveness: Beyond Formalism. Vlerick Leuven Gent Working Paper Series 2007/03. http://hdl.handle.net/20.500.12127/2267.

Mar, P., \& Young, M. N. (2001). Corporate Governance in Transition Economies: A Case Study of Two Chinese Airlines. Journal of World Business, 36(3), 280-302. https://doi.org/10.1016/S1090-9516(01)00056-6.

Melkumov, D., \& Khoreva, V. (2015). The Effect of Board Capital and Conflict on the Tasks of the Board of Directors. International Studies of Management \& Organization, 45(1), 60-79. https://doi.org/10.1080/00208825.2015.1005998.

Menozzi, A., Urtiaga, M, G., \& Vannoni, D. (2012). Board Composition, Political Connections And Performance in State-Owned Enterprises. Industrial and Corporate Change, 21(3), 671-698. https://doi.org/10.1093/icc/dtr055.

Minichilli, A., Zattoni, A., \& Zona, F. (2009). Making Boards Effective: An Empirical Examination of Board Task Performance. British Journal of Management, 20(1), 55-74.https://doi.org/10.1111/j.1467-8551.2008.00591.x.

Mizruchi, M. S. (1996). What Do Interlocks Do? An Analysis, Critique, and Assessment of Research on Interlocking Directorates. Annual Review of Sociology, 22(1), 271-298. https://doi.org/10.1146/annurev.soc.22.1.271.

Mostivenko, T. (2017). The Relationship Between Intellectual Capital of Board of Directors and IPO Performance of Russian Companies: Comparative Analysis of MOEX and LSE. (Master in Management Program), St. Petersburg University. Mugobya, J. B. (2016). Board Roles And Performance of National Water and Sewerage Corporation (NWSC) in Uganda. (Master's in Public Administration And Management), Uganda Technology and Management University. 
Müller, V.-O. (2014). Do Corporate Board Compensation Characteristics Influence the Financial Performance of Listed Companies. ProcediaSocial and Behavioral Sciences, 109(Supplement C), 983-988.

Nicholson, G. J., \& Kiel, G. C. (2004). A Framework for Diagnosing Board Effectiveness. Corporate Governance: An International Review, 12(4), 442-460. https://doi.org/10.1111/j.1467-8683.2004.00386.x.

Offstein, E. H., \& Gnyawali, D. R. (2006). A Humanistic Perspective of Firm Competitive Behavior. Competitiveness Review: An International Business Journal, 16(3/4), 248-261. https://doi.org/10.1108/cr.2006.16.3_4.248.

Pettigrew, A. M. (1992). On Studying Managerial Elites. Strategic Management Journal, 13(2), 163-182. https://doi.org/10.1002/smj.4250130911.

Pfeffer, J. (1972). Size and Composition of Corporate Boards of Directors: The Organization and Its Environment. Administrative Science Quarterly, 17(2), 218-228. https://doi.org/10.2307/2393956.

Sheikh, N. A., \& Wang, Z. (2012). Effects of Corporate Governance on Capital Structure: Empirical Evidence from Pakistan. Corporate Governance: The International Journal of Business in Society, 12(5), 629-641. https://doi.org/10.1108/14720701211275569.

Shukla, D. M, \& Dwivedi, N. (2016) Influence of Board of Directors on Corporate Diversification: Evidence from India. Review of Financial Economics, 25(5), 471-484. https://doi.org/10.1002/jsc.2074.

Sonnenfeld, J. A. (2002). What Makes Great Boards Great. Harvard Business Review, 80(9), 106-113.

Starr, P. (1988). The Meaning of Privatization. Yale Law \& Policy Review, 6(1), 6-41. Stewart, T. A. (1997). Intellectual Capital, Currency: Doubleday, New York.

Stiles, P. \& Taylor, B. (2001) Boards at Work: How Directors View Their Roles and Responsibilities. Oxford University Press.

Tecker, G. H., \& Fidler, M. (1993). The Better Board's Role. Leadership, 10-16.

Westphal, J. D., \& Bednar, M. K. (2005). Pluralistic Ignorance in Corporate Boards and Firms' Strategic Persistence in Response to Low Firm Performance. Administrative Science Quarterly, 50(2), 262-298. https://doi.org/10.2189/asqu.2005.50.2.262.

Yatim, P. (2013). Directors' Remuneration and Corporate Governance in Malaysia. Paper Presented at the 7th Asia Pacific Interdisciplinary Research in Accounting Conference.

Zahra, S. A. \& Pearce, J. A. (1989). Boards of Directors and Corporate Financial Performance: A Review and Integrative Model. Journal of Management Studies, 15(2), 291-334. https://doi.org/10.1177/014920638901500208.

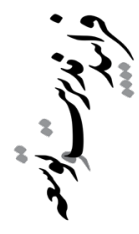

